\title{
MINERALOGICAL FOOTPRINTS OF MICROBIAL LIFE
}

\author{
SUSANNE DOUGLAS \\ Jet Propulsion Laboratory, Astrobiology Research Element, MS183-301, 4800 Oak \\ Grove Drive, Pasadena, California 91109-8099; Susanne.Douglas@jpl.nasa.gov
}

\begin{abstract}
This paper is dedicated to Dr. Terry J. Beveridge, mentor and friend, on the occasion of his 60th birthday.
\end{abstract}

\begin{abstract}
Earth's geosphere is intimately tied to its biosphere. A major link between the two lies in the microbial realm; microorganisms grow in and upon rocks and minerals, often relying on their substratum for critical compounds needed in order to produce cellular energy. The presence of a metabolizing cell on a mineral substrate has a significant effect on the mineral texture and on the geochemistry of the surrounding microenvironment. In nature, microorganisms exist in microbial communities as mats or biofilms growing upon a solid substrate. As such they cover a vast surface area both within and below the surface of Earth's land and sea. The following review will provide a glimpse into the latest findings in the field of geomicrobiology and is intended to convey a sense of the profound influence microorganisms can have upon the geological environment they inhabit.
\end{abstract}

\section{INTRODUCTION}

The field of geomicrobiology has grown dramatically over the last decade so that a true review of the work done would encompass several thick volumes. The present summary, therefore, is intended to highlight the most recent and exciting works of significance in the field within the context of the founding studies. Every effort will be made to point the reader to the appropriate literature for review of earlier studies and details of the basic principles regarding mechanisms of interaction between microorganisms and minerals. In addition, this paper will focus mainly on bacteria, since this is where the bulk of the research has been done. Microorganisms are ubiquitous in and on Earth and can be found in almost any type of environment from clement to harsh. In fact, the only places where they haven't been found seem to be the places where we haven't specifically looked for them. Excluding those that live in or upon animals or plants, these organisms are also intimately tied into the geosphere, playing a major role in the dynamic processes that shape the Earth. I will examine some of these processes, describe the results of laboratory studies and relate these to field observations and measurements.

MINERAL FORMATION ON BACTERIAL CELLS

Most studies of microbe-mineral interactions have focused on bacterial cells; under extreme environmental conditions, these become the dominant life forms. In many environmental samples, examination by transmission electron microscopy reveals mineral precipitates closely associated with bacterial cells. Among the characteristics of bacteria that make them ideal nucleating agents for mineral precipitation is that individual cells are very small, especially in low-nutrient environments. On average, a single rod-shaped bacterium will have a diameter of approximately $0.5 \mu \mathrm{m}$ and a length of $1 \mu \mathrm{m}$ (Beveridge, 1981). Due to their small size, bacteria as a group have the highest surface area-to-volume ratio of any group of living organisms and this, together with the presence of charged chemical groups on their cell surface, is responsible for the potent mineral nucleating ability of these cells. Bacterial cell walls come in two main formats, Gram positive or Gram negative as discovered by Christian Gram in 1885 (from Beveridge, 1981). Either type may be overlain by a number of other surface 
structures. These may be proteinaceous in nature (for example, S-layers) or composed (primarily) of carbohydrate polymers (for example, capsules and sheaths) and may occur singly or in combination; a more detailed description of these structures can be found in (Beveridge, 1981) and (Schultze-Lam and others, 1993). Whatever types of cell surface structure the cell may have, the main charged chemical constituents found in these structures at neutral $\mathrm{pH}$ are carboxyl, phosphoryl, and amino groups. In general, negatively charged groups dominate over positively charged ones, giving the cell surface an overall anionic charge (Beveridge, 1981).

Initiation of mineral formation on bacterial surfaces has been proposed to follow a generalized pattern which can be thought of as occurring in two steps (Beveridge and Fyfe, 1985). In the first step, metal ions present in the aqueous surroundings of the cell interact with charged groups in the surface structures. The interaction is stoichiometric such that there is an electrostatic charge complementation between the charged groups in cellular polymers and the metal ions. Subsequently, the presence of bound metal ions in the wall fabric lowers the total free energy of the system, thereby initiating further metal deposition. In this case, precipitates form at the nucleation site between metal ions and excess counter ions from the fluid phase; the wall binds more metal ions than would have been expected based solely upon charge interactions with wall polymers. Thus, metal aggregates are formed within the wall matrix, their size constrained by the physical presence of the polymer meshwork itself. Depending on microenvironmental geochemistry, negatively charged counterions (for example, sulfate, phosphate, carbonate, sulfide, or silicate ions) determine specific mineral phases (Beveridge, 1981). Mineral formation on the bacteria is generally not controlled by the organism; it happens because of the physicochemistry of the bacterial surface and the chemistry of the cell's environment. Actively metabolizing bacteria with highly energized plasma membranes can inhibit mineral formation since the cell wall is flooded with protons that compete for binding sites with metal cations (Urrutia and others, 1992).

Microbe-mineral interactions involve not only the formation of minerals by microorganisms but also the degradation of minerals. This activity leads to the formation of fine grained recognizably biogenic minerals; it also produces distinct microbial textures or "fabrics" (fig. 1). There is a spatial and conceptual continuum, which connects the fine scale $(\mathrm{nm})$ to the macroscale $(\mathrm{cm})$. On the most fundamental level, microorganisms can affect mineral formation and dissolution kinetics (Warren and Haack, 2001) by a variety of mechanisms. These mechanisms can be roughly divided into two main types: 1 ) passive, where the simple presence of the microbial cell itself acts as a catalyst for mineral formation (reviewed in detail by Beveridge, 1981; Ehrlich, 1999; Frankel and Bazylinski, 2003), and active, where microbial metabolism indirectly affects mineral formation or dissolution by altering microenvironmental geochemistry (fig. 2). Microorganisms are surrounded by a unique microenvironment that is distinct from the bulk environment. Even under the driest conditions, bacterial cells are surrounded by a layer of water molecules. This water may consist solely of bound water molecules, which are structurally integrated into the macromolecular framework of the cell itself, often aided by specific microbially derived molecules that are produced for the purpose of desiccation tolerance. These serve to order the water molecules into particular, molecularly protective arrays (Potts, 1994). At the other end of the spectrum, consider a bacterial cell that is planktonic. It is surrounded by an envelope of water molecules that may be several hundreds of nanometers thick, and which becomes more and more disordered with distance away from the bacterial cell surface. This envelope acts as a diffusion barrier around the cell, concentrating microbial metabolic products and limiting the concentration near the cell of aqueous constituents from the bulk environment (van Loosdrecht and others, 1990). Often, 


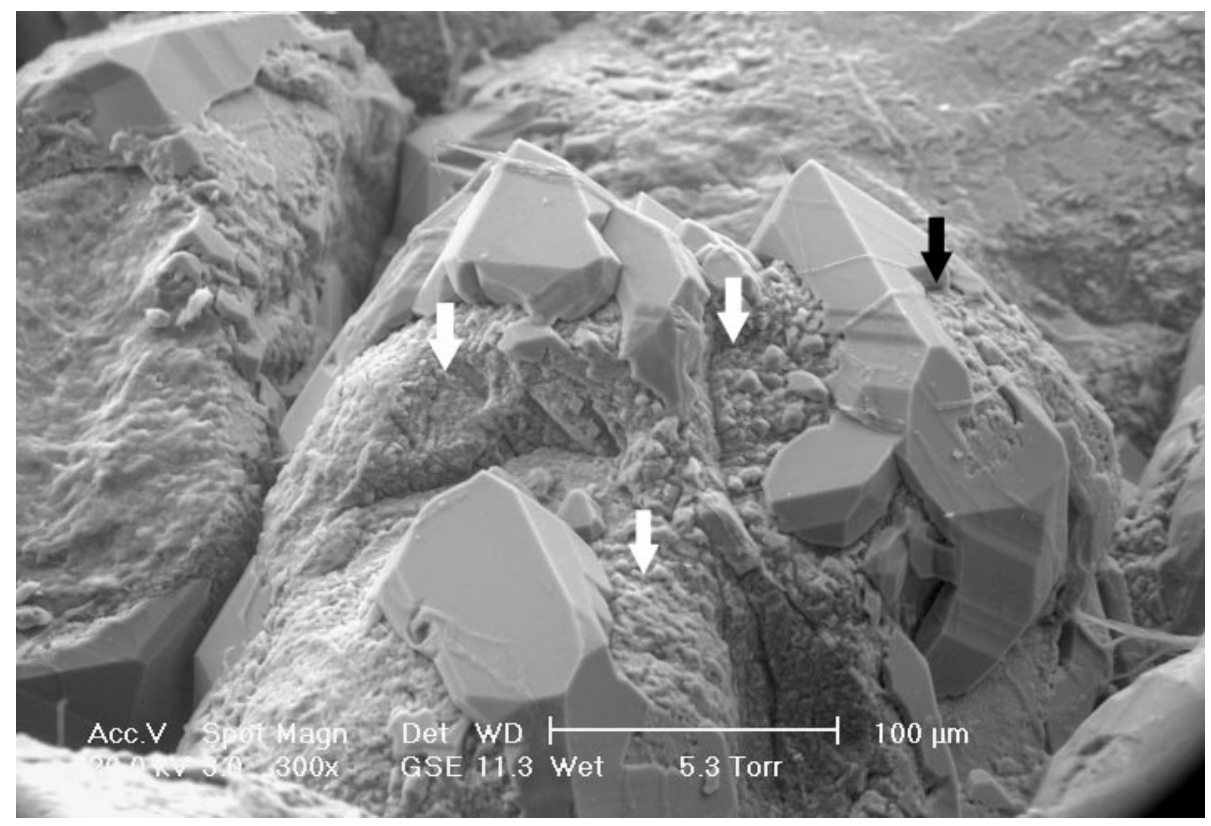

Fig. 1. Environmental scanning electron microscope (ESEM) image of a colonized sandstone from the Antarctic dry valleys. The microbial biofilm (white arrows) appears as an aggregate of small particles with occasional filaments traversing clear quartz crystal faces. These biofilms consist of microbial cells (identified by EDS and morphology) coated with reprecipitated minerals (mostly amorphous silica and clays). Note how the biofilms seem to have etched depressions (black arrow) into the quartz grains. Bar $=100 \mu \mathrm{m}$.

this boundary layer can be extended many microns away from the cell wall by the formation of microbially-derived cell surface polymers-capsules, slime or sheath. This is a common characteristic of bacteria from natural environments (Douglas and Beveridge, 1998). The loose term for these structures is 'extracellular polymeric substance" or EPS. EPS consists mainly of carbohydrate polymers, which may or may not have other types of polymers interwoven, such as peptides. In general, EPS hosts a large density of electrostatically negative (at neutral $\mathrm{pH}$ ) charged groups intrinsic to the EPS and these, like the cell wall polymers themselves, have a strong influence on microbial mineral formation (Geesey and others, 1988; Little and others, 1997).

\section{Microorganisms in Nature}

In nature, microorganisms occur as microbial communities: diverse types of microorganisms co-existing as a cohesive mat or biofilm of cells embedded in EPS and generally growing upon a solid substratum. Thus, not only are there diffusion barriers created around each cell but also through the thickness of the mat or biofilm. As a result, such mats, which can be micrometers to centimeters thick, but most commonly 1 to $10 \mathrm{~mm}$, exhibit chemical, structural, and population stratification as each type of microorganism attempts to stay within the zone where its chemical and physical needs are most optimally met. This activity, also affects local geochemistry with consequences for mineralogy of the local environment.

Carbonaceous organosedimentary structures known collectively as microbialites provide the best studied examples of mineralized microbial communities. Such structures have been preserved in the geological record, providing information of past geomicrobiological activity and environmental conditions. Extant microbialites are presently still forming in certain environments, usually warm shallow (marine) waters 


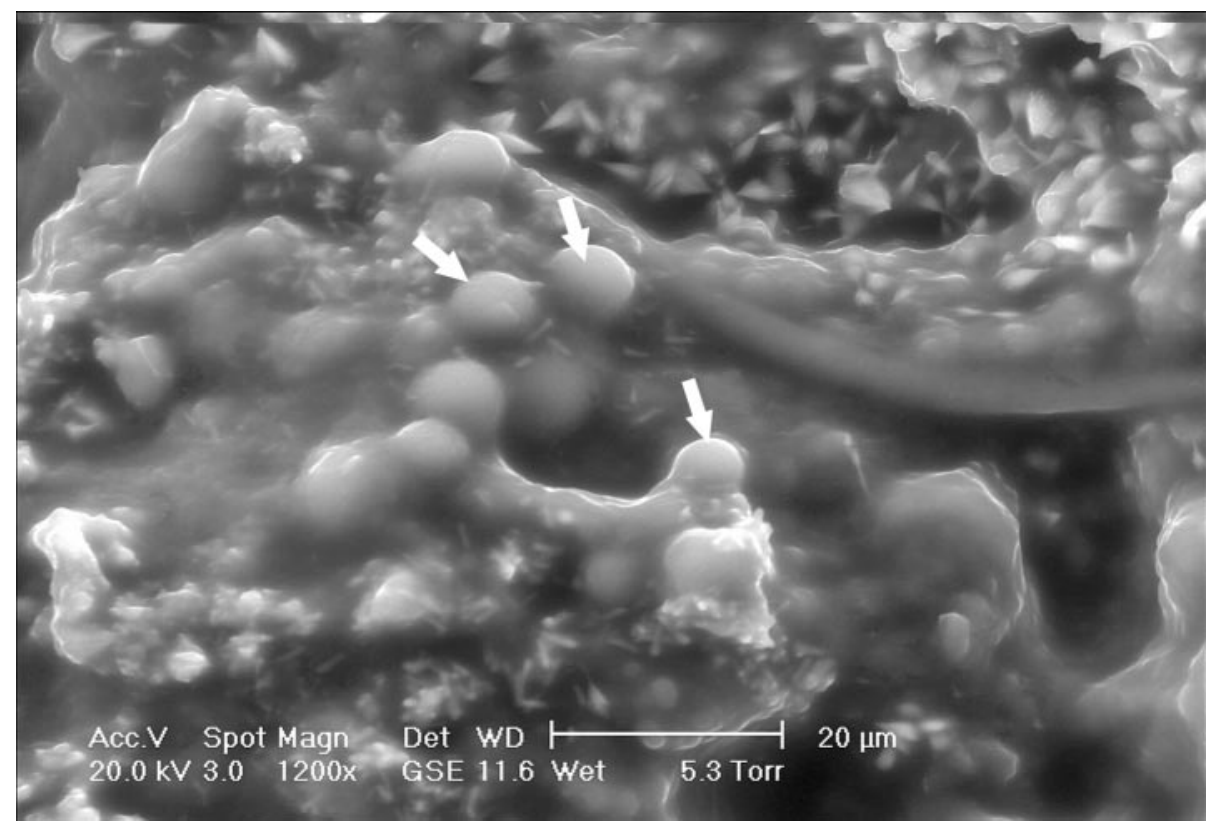

Fig. 2. ESEM image of a microbial mat from a hypersaline pond on Lee Stocking Island, Bahamas. Large round cells (white arrows) occupy a zone free of minerals but are overlain by a layer rich in mineral precipitates. The different components of the sample were identified by morphology and by EDS (for elemental composition) and X-ray diffraction (for mineralogy). The chemical microenvironment created within the mat, which was $30 \mathrm{~cm}$ thick, shows gradients, reflected in the spatial segregation of mineralized vs. non-mineralized zones, seen in this image. Here, the minerals in the upper part of the region shown were celestite $\left(\mathrm{SrSO}_{4}\right)$, as confirmed by EDS and XRD within a layer of purple sulfur bacteria (confirmed by light microscopy) and as cells by EDS. Bar $=20 \mu \mathrm{m}$.

which provide adequate light and shelter from disruptive physical forces and protection from grazing invertebrates (for example, molluscs). Numerous excellent reviews exist, which describe stromatolites (Kennard and James, 1986; Burne and Moore, 1987) and their formative mechanisms (Pentecost, 1987, 1988; Thompson and others, 1990; Kempe and others, 1991; Krumbein and others, 2003). As such, the focus here will be on the lesser known mineralized microbial communities that have only recently become known, especially those in siliciclastic environments.

\section{Bacteria and Sulfur Minerals}

The transformation of reduced sulfur (sulfide) to oxidized forms (sulfate) via various intermediate forms, represents an important energy-yielding pathway for chemosynthetic microorganisms (summarized by Ehrlich, 1996). Sulfur compounds are among the most energy rich inorganic chemical compounds available to microorganisms. From sulfide (2-) to sulfate $(6+)$, a total of 8 electrons can be exchanged in a step wise manner to yield not only energy for the organisms, but also a wide variety of mineral products. These, in turn, can often undergo redox transformations of their own (Jorgensen and others, 2004).

Geomicrobiology of a cold sulfide spring.-A study of a cold sulfide spring emanating from a dolomite/gypsum host rock in a temporal climate region allowed some speculation as to the place for minerals of varying form in sulfur cycling (Douglas and Douglas, 2000, 2001). The spring arises from a groundwater source which flows along the contact between a gypsum $\left(\mathrm{CaSO}_{4} \cdot 2 \mathrm{H}_{2} \mathrm{O}\right)$ and dolomite $\left(\mathrm{CaMg}\left(\mathrm{CO}_{3}\right)_{2}\right)$ stratum. As a result, the groundwater contains significant levels of dissolved sulfate and is of $\mathrm{pH}$ 
7.4 to 8.0. Sulfate reducing bacteria living in microbial communities on the solid walls of the rock strata are responsible for reducing the sulfate to $\mathrm{H}_{2} \mathrm{~S}$ so that by the time the waters emerge at the ground surface they are highly charged with this reduced form of sulfur and the redox potential has gone from +300 to $-300 \mathrm{mV}$ (that is, the waters are highly anoxic as they emanate from the spring source). As the spring water spills out and traverses the floor of a narrow ravine, the sulfide is oxidized microbially to elemental sulfur by a conspicuous white filamentous biofilm choking the channel bottom. In the spring mouth itself, sulfur is oxidized also, but by photosynthetic microorganisms (purple sulfur bacteria, and green sulfur bacteria) that use the sulfide as an electron donor for photosynthesis, depositing sulfur in elemental form as a vesicular colloid (fig. 3). One of the novel findings of this study was a type of cyanobacterium that was filamentous, with each cell shaped like a peanut shell. At the septa between cells, intracellular sulfur globules were accumulated. The identification of this organism as a cyanobacterium and the globules as sulfur deposits were confirmed by transmission electron microscopy/EDS, environmental scanning electron microscopy/EDS, and light microscopy, with a special silver-based stain to highlight the sulfur. Attempts to culture this organism were unsuccessful but it was the dominant cyanobacterial form in the spring, both anoxic and oxic zones. Further down the stream channel, as organic debris-degrading organisms begin to dominate and the $\mathrm{pH}$ of the stream drops to 6.0, the elemental sulfur is broken down into sulfite, thiosulfate, and sulfate for incorporation into microbial and plant metabolic pathways, mainly for the production of structural molecules such as amino acids.

Microbe-mineral relationships in evaporite deposits. - Other sulfur rich environments such as deep sea hydrothermal vents, meromictic lakes, and hypersaline lagoons, host rich assemblages of microorganisms driven by similar sulfur cycle reactions and these

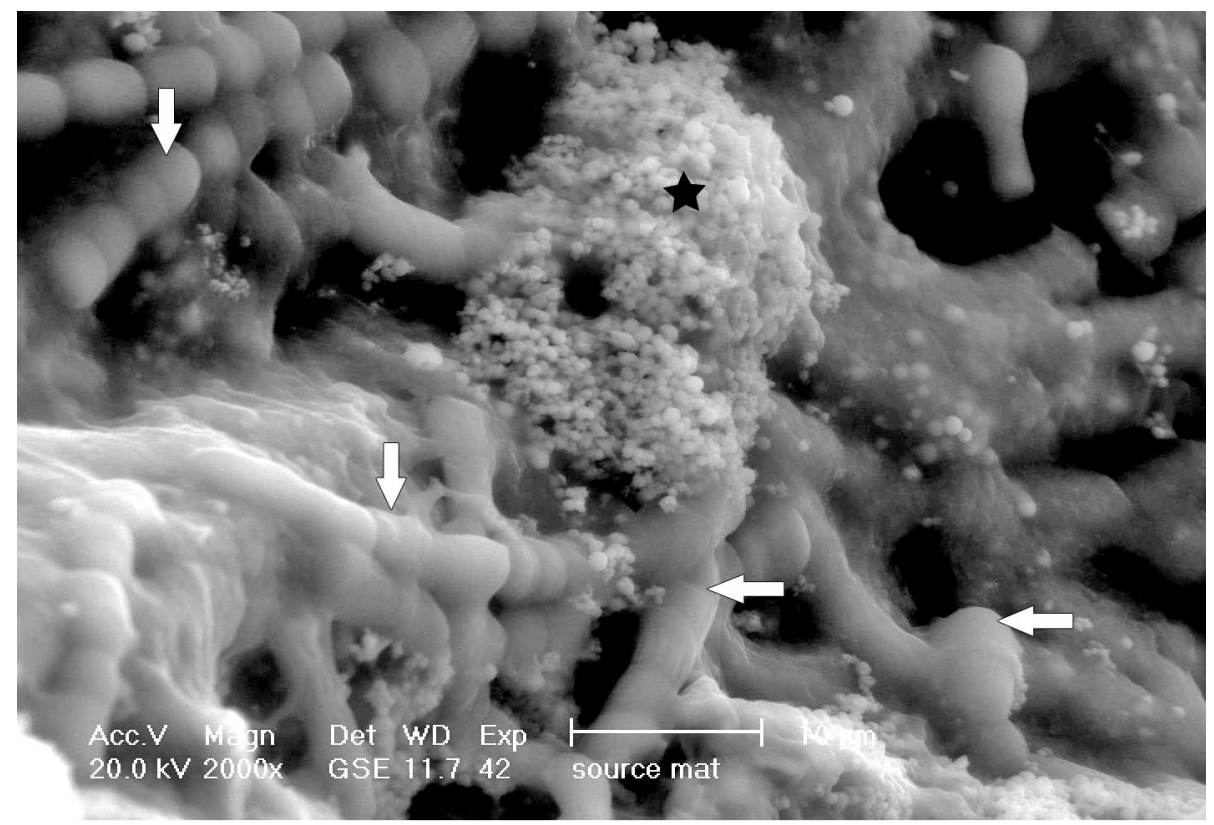

Fig. 3. ESEM image of a microbial mat from the anoxic region of a cold sulfide spring. The long chains of cells are cyanobacteria (arrows), which can use sulfide as an electron donor for photosynthesis and consequently deposit colloidal sulfur (star) externally. Such an ability has been proven for cyanobacteria (mainly Oscillatoria) in other environments. Bar $=10 \mu \mathrm{m}$. 
environments host a comparable set of minerals, formed by microbially-driven mechanisms (Krumbein and others, 1977). Most recently, investigations of endolithic microbial communities within evaporite deposits have shown that, here, too, unique biogenic minerals are deposited. A study of gypsum $\left(\mathrm{CaSO}_{4} \cdot 2 \mathrm{H}_{2} \mathrm{O}\right)$-hosted endoliths in Death Valley, California (Douglas and Yang, 2002) revealed that organisms were able to precipitate the Sr-rich minerals celestite $\left(\mathrm{SrSO}_{4}\right)$ and strontianite $\left(\mathrm{SrCO}_{3}\right)$ as well as calcite $\left(\mathrm{CaCO}_{3}\right)$ within the layered community. Each mineral type was segregated into a restricted chemical zone together with a specific microbial type that helped create the chemical conditions present at that particular depth in the community. Most unusually, a form of elemental sulfur, rosickyite (gamma sulfur) was found to be abundantly associated with the anoxic face of the cyanobacterial layer in this community (fig. 4). Previously, rosickyite was thought to be a purely abiotic, hydrothermally deposited mineral (Meisser and others, 2000). The layering of organisms and minerals as well as the chemical stratification occurred on scales of millimeters. The colonized zone within the evaporite deposit was also easily recognizable due to a microbiallyinduced textural alteration. Where organisms were abundant, large deposits of finegrained ( $\mu \mathrm{m}$ to nm scale) mineral grains are present, in comparison to the planar faces of unaltered minerals (fig. 5).

Cave geomicrobiology.- One of the most fascinating discoveries of recent years is the wide range of mineral types and morphologies formed in association with microorganisms in caves. These environments, which of necessity host non-photosynthetically based communities (Sarbu and Popa, 1992; Sarbu and others, 1994) represent a rich opportunity to see what chemosynthetic life processes can do to local geology. Both carbonate rock and gypsum beds can be reworked by microbially-induced acid dissolution, forming elaborate karst landforms. (Pochon and others, 1964; Andrejchuk and Klimchouk, 2001; Cañaveras, and others, 2001; Engel and others, 2004). The activity of microorganisms in caves has resulted in the reworking of cave architecture

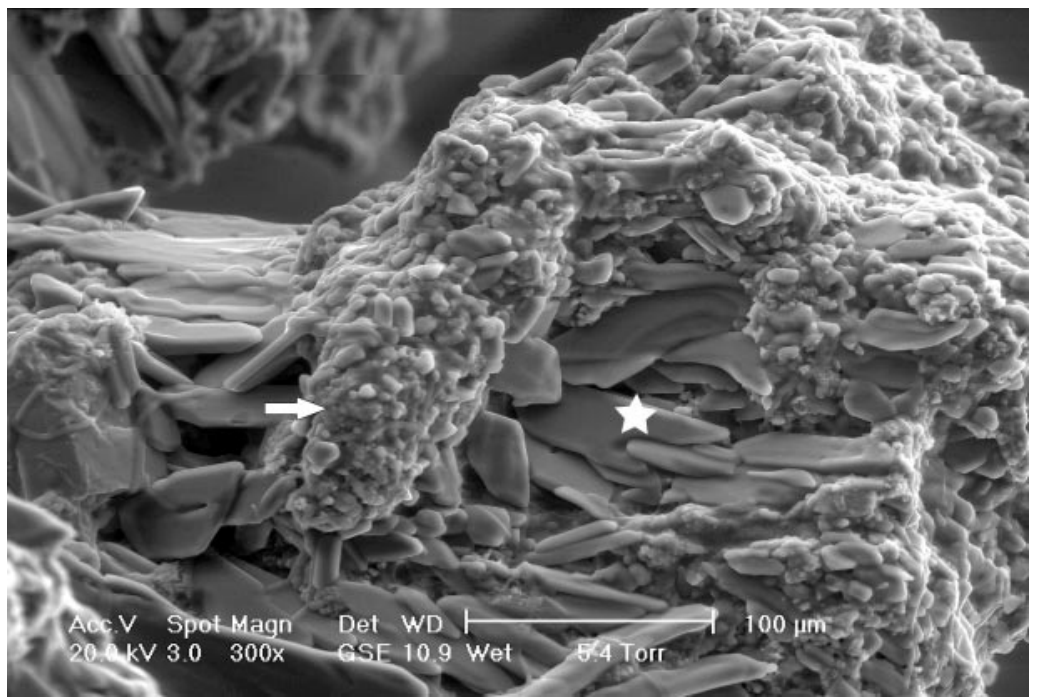

Fig. 4. Cyanobacterial biofilm (arrow) with long, bladed roscikyite (gamma sulfur) crystals in an endolithic community from Badwater, Death Valley. The cyanobacteria (identity based on light microscopy and EDS as well as ESEM) are enclosed within extracellular polymers and mineral precipitates. Rosickyite (for example, star) was identified based on crystal morphology as well as EDS and XRD. The host rock is gypsum and the cyanobacteria occupy a zone between the upper oxic layer and the lower anoxic layer, where conditions are just right for this mineral to form. Bar $=100 \mu \mathrm{m}$. 


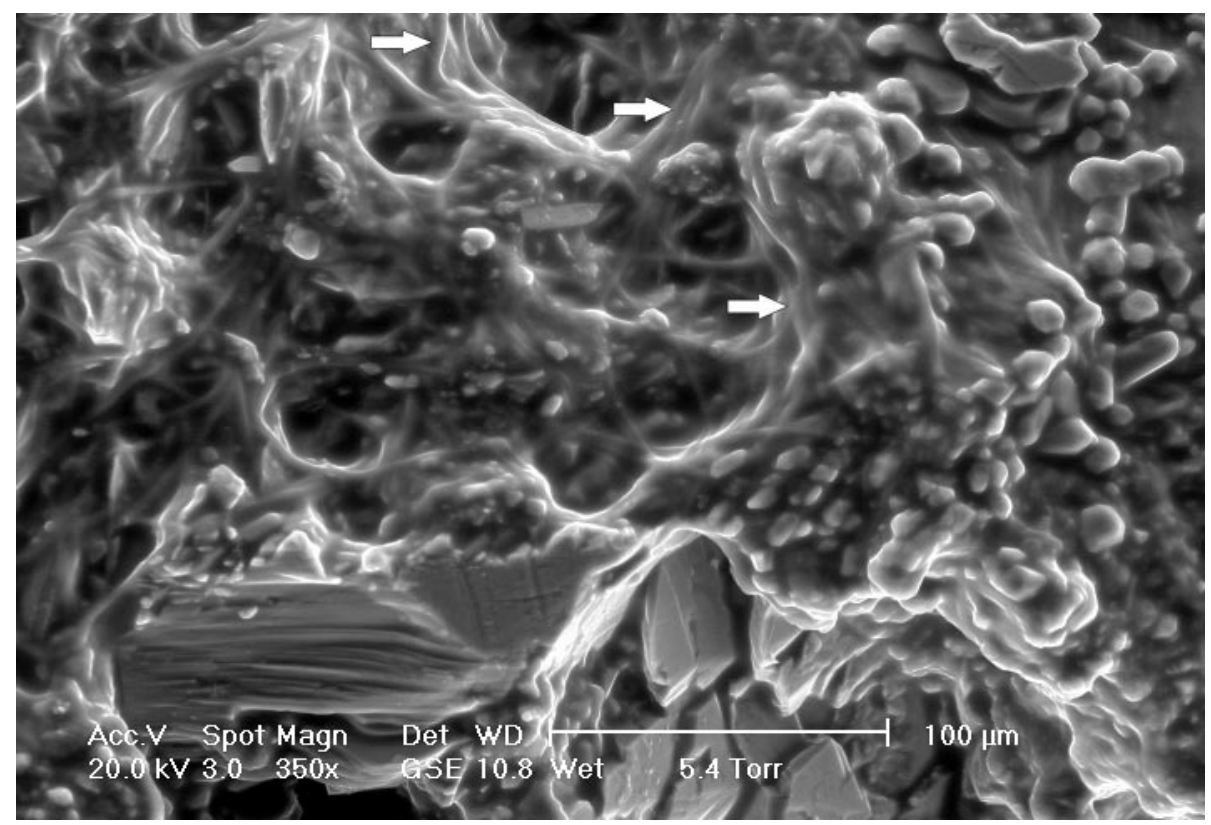

Fig. 5. General appearance of the microbial layer of the Death Valley endolith (upper part of image) in comparison to the host rock (gypsum) grains visible in the lower part of the image. It is immediately clear that there is a strong textural difference between the two regions. Note that the microbial filaments (arrows) are enclosed in a gel-like EPS or slime layer. By ESEM, the EPS layer remains as an amorphous film rather than drying into strands as they would by conventional SEM. Therefore the filaments are microbial trichomes (also seen in light microscopy of the same sample). Bar $=100 \mu \mathrm{m}$.

and the production of complex and beautiful formations, reviewed by Northup and Lavoie (2001). This is a result of both microbially mediated dissolution and the precipitation of secondary mineral phases or "speleothems."

Speleothems are formed by a physicochemical reaction from primary mineral in a cave (Moore, 1952; Cox and others, 1989; Provencio and Polyak, 2001). Reduced compounds in cave wall rock can be microbially oxidized to form secondary mineral deposits on top of the biofilm, dissolved rock underneath the biofilm, and acidic microenvironmental waters. For example, the metabolic processes of sulfur-iron-, and manganese-oxidizing bacteria (Sarbu and others, 1994) can generate considerable acidity, dissolving cave walls and formations (Andrejchuk and Klimchouk, 2001; Engel, and others, 2004). This leads to the formation of sharp redox boundaries at the microbe-mineral interface as the microorganisms use elements from the geological matrix of the cave wall to produce energy in this organic nutrient-limited environment (Andreychuk and Klimchouk, 2001). These biogenic minerals range from carbonates (moonmilk), silicates, clays, iron and manganese oxides, to sulfur, and saltpeter (potassium nitrate) at scales ranging from microscopic to macroscopic (Hill and Forti, 1997). As a result of such activity, streams only meters apart can have vastly different chemical compositions. One of the most common reactions is the formation of sulfuric acid from sulfide (either atmospheric hydrogen sulfide or cave wall sulfide minerals) by bacteria similar to Thiobacillus species (Engel and others, 2004). This is the same type of reaction that leads to acid mine drainage formation in ore tailings piles (Southam and Beveridge, 1992; Fortin and others, 1995, 1996; Fortin and Beveridge, 1997). In caves, sulfuric acid often dissolves carbonate minerals present, widening the passages of limestone caves, and liberating elements such as calcium, magnesium, iron, 
and manganese to be transported to and concentrated in other areas of the cave, usually by microorganisms (Northup and Lavoie, 2001).

\section{Microbial Involvement in Dolomite Formation}

Present-day low-temperature dolomite formation is most active in restricted marine or hypersaline coastal environments, where fluids are greatly supersaturated with respect to dolomite (for example, Carballo and others, 1987; Vasconcelos and others, 1995; Wright, 1997; Vasconcelos and McKenzie, 1997; van Lith and others, 2002). Freshwater dolomite is present in the rock record, although few modern locales exist where it is actively being formed. Capo and others (2000) reported pedogenic dolomite associated with young basaltic soils on the island of Hawaii, where the alteration of ferromagnesian minerals by infiltrating water supplied the $\mathrm{Mg}$ for precipitation of well-ordered dolomite. Modern dolomite precipitation is often associated with dissimilatory sulfate reducing bacteria that remove sulfate, produce alkalinity, and presumably drive dolomite formation (for example, Vasconcelos and McKenzie, 1997; Wright, 1999). The isotopic ratios of organic carbon in ancient dolomites indicate that high rates of carbon oxidation and methanogenic conditions also favor dolomite formation (for example, Mozely and Burns, 1993). This finding supports the growing realization that near-surface, low temperature dolomite forms in association with microorganisms in a wide range of environments.

Dolomite and sulfate reducing bacteria.-Vasconcelos and others (1995) contributed a new, microbiological perspective to global dolomite studies based on their study of a coastal lagoon (Lagoa Vermelha) which is located in an unusual hydrological and climatic setting. The region is dominated by a semi-arid micro-climate, which leads to extreme hypersalinity (salinity $>4.0 \%$ ) of the lagoon during the dry season. Intense evaporation increases the salinity and lowers the water level, permitting the inflow of seawater to supply ions for microbial processes. During the wet season, precipitation exceeds evaporation, resulting in large variations in salinity, sometimes reaching brackish conditions (that is, salinity is $<2.5 \%$ ). Dolomite apparently precipitates under the most hypersaline conditions, whereas high- $\mathrm{Mg}$ calcite forms at intermediate salinity and low-Mg calcite during periods with brackish water (Vasconcelos and McKenzie, 1997). Relatively high productivity in Lagoa Vermelha leads to anoxic conditions at the water-sediment interface and formation of a black, organic, carbonrich sludge. Microbial activity apparently mediates the precipitation of carbonate minerals within the sludge layer. When sulfate-reducing bacteria use $\mathrm{SO}_{4}{ }^{2-}$, they also take up $\mathrm{Mg}^{2+}$ because it forms a strong ionic pair with $\mathrm{SO}_{4}{ }^{2-}$; the microorganisms overcome the kinetic barriers by using $\mathrm{SO}_{4}{ }^{2-}$ for their metabolism. At the same time they release $\mathrm{Mg}^{2+}$ from the ion pair. On a submicrometer scale, the bacterial metabolism saturates the microenvironment around the cell with $\mathrm{HCO}_{3}{ }^{-}$, creating conditions favorable for preferential precipitation of dolomite. The microbially nucleated crystals are subsequently buried, where the initially formed Ca-dolomite undergoes an "aging" process, whereby inorganic recrystallization occurs to produce a more stoichiometric dolomite (Vasconcelos and Mckenzie, 1997; van Lith and others, 2002).

Dolomite and sulfide oxidizing bacteria.-A different microbial mechanism is suggested by Moreira and others, (2004) who describe Brejo do Espinho, another lagoon in the vicinity, where active sulfide oxidation is postulated to be the source of the larger quantity of more stoichiometric dolomite in lagoonal deposits. Pore waters in this lagoon system are characterized by rapid sulfide oxidation, dynamic carbon-sulfur cycling, low degrees of carbonate mineral saturation, and hypersalinity poised below gypsum saturation. It is proposed that sulfide oxidation maintains undersaturation with respect to $\mathrm{Mg}$-calcite and aragonite and supersaturation with respect to dolomite, making this marginal marine environment exceptionally conducive to dolomite precipitation (Moreira and others, 2004). Subsurface fluid is drawn upward by evapotranspira- 
tion from magnesium-rich sources such as other nearby lagoons and seawater. At depth, recrystallizaton and further ordering of the dolomite structure probably occurs, as in the "aging" process proposed by Vasconcelos and McKenzie (1997). Sulfide oxidation may occur abiotically or may be mediated by cooperative lagoonal microbial communities, in which the product of one microorganism (here, $\mathrm{H}_{2} \mathrm{~S}$ from sulfate reducers) may provide the substrate for another microbial process (sulfide oxidation). These microorganisms may further promote dolomite precipitation by providing charged nucleation surfaces.

Sulfide oxidation in hypersaline coastal lagoons as described by Moreira and others (2004), provides the thermodynamic and geochemical conditions required for the massive marginal marine dolomites observed in the rock record. Although modern hypersaline lagoons are not areally extensive, periods of increased dolomite formation have been correlated with periods of elevated sea level when restricted shallow intracontinental seas were widespread (Mackenzie and Morse, 1992). Also, the proposed mechanism does not rely on a specific dolomitizing environment or require high degrees of supersaturation for dolomite, but invokes several key factors to explain dolomite formation: undersaturation of high-Mg calcite accompanied by moderate undersaturation for dolomite, continuous flux of $\mathrm{Mg}$, normal marine $\mathrm{Mg} / \mathrm{Ca}$ ratios, and moderate degrees of sulfate reduction typical of modern environments. The recurrence of these factors in seawater and modified seawater environments may be a fundamental control on dolomite production rates in the geologic record (Moreira and others, 2004). Thus, it may be the coupling between sulfide oxidation and sulfate reduction (Vasconcelos and McKenzie, 1997) that produces the chemical conditions necessary for dolomite precipitation.

Microbially mediated dolomite precipitation was a significant discovery in geology due to the persistence of the dolomite mystery. Dolomite $\left(\mathrm{CaMg}\left(\mathrm{CO}_{3}\right)_{2}\right)$ is found in much greater abundance in ancient rocks than in modern carbonate environments. Modern dolomite is largely limited to evaporitic marginal marine environments such as the Coorong Lakes, South Australia (Von der Borch, 1965; Rosen and others, 1989) and the sabhkas of Abu Dhabi, United Arab Emirates (Evans and others, 1969; McKenzie and others, 1980). Finding authigenic dolomite deposition in a modern environment enables elucidation of the conditions necessary for its formation. This information can then be extrapolated into the past in order to shed light on the patterns of dolomite deposition in the geological record. In particular, periods of more extensive dolomitization broadly correlate with diverse indicators of decreased oxygen levels in the atmosphere and oceans (Burns and others, 2000). Lowered oxygen levels would have fostered a more active community of anaerobic microbes, including sulfate reducing bacteria, which, in turn, could have led to more extensive dolomitization of marine carbonates.

Dolomite formation by methanogens.-Another environment in which dolomite has been found actively forming is in the Bemidji aquifer, near Richland, Washington, where a basalt-hosted subterranean water body is contaminated with refractory organics. Here, a third mechanism of microbially mediated dolomite precipitation was invoked, this time involving methanogens. The waters of this aquifer are anoxic, allowing an extensive community of methanogenic microorganisms to develop (Stevens and others, 1993). Here, microbial precipitation of dolomite occurs under highly reducing conditions in the form of minerals precipitated directly on microbial cell surfaces (Roberts and others, 2004). Unlike other modern examples of low temperature dolomite formation (for example, Whipkey and others, 2002), in the subsurface, precipitation occurs from dilute solutions (as compared to ones in which the waters are supersaturated with respect to dolomite) that are near equilibrium with dolomite and have relatively low Mg:Ca ratios $(<1)$. Changes in the geochemistry of the contami- 
nated zone suggest accelerated dissolution of silicates (Bennett and others, 2001). Dissimilatory iron reducing bacteria are the dominant metabolic type within the contaminated zone coexisting with methanogens that are found in narrow spatially distinct zones (Bekins, and others, 1999). As the colonized basalt weathers to clay, it releases $\mathrm{Ca}, \mathrm{Mg}$, and $\mathrm{Fe}$ into a neutral $\mathrm{pH}$ groundwater that is near equilibrium with calcite and dolomite and has a high concentration of $\mathrm{Fe}^{2+}$ and dissolved $\mathrm{CH}_{4}$. Basalt dissolves only near attached cells, as colonizing microorganisms destroy the silicate to access apatite inclusions in this P-limited groundwater (Rogers and others, 1998). At the surface of the dissolving basalt, it is hypothesized (Roberts and others, 2004) that methanogens locally initiate precipitation of ferroan dolomite by consuming $\mathrm{CO}_{2}$ in an environment of released $\mathrm{Ca}, \mathrm{Mg}$, and $\mathrm{Fe}$, driving the system even farther toward carbonate supersaturation:

$$
\begin{aligned}
3 \mathrm{HCO}_{3}^{-}+4 \mathrm{H}_{2}+0.1 \mathrm{Ca}^{2+}+ & 0.9 \mathrm{Mg}^{2+}+0.1 \mathrm{Fe}^{2+} \rightarrow \\
& \mathrm{Ca}_{0.1} \mathrm{Mg}_{0.9} \mathrm{Fe}_{0.1}\left(\mathrm{CO}_{3}\right)_{2}+\mathrm{CH}_{4}+3 \mathrm{H}_{2} \mathrm{O}+\mathrm{H}^{+} .
\end{aligned}
$$

Observations from this field site suggest that extreme supersaturation and high Mg:Ca ratios were not necessary for dolomite precipitation but rather that microbial cell walls nucleate dolomite in freshwater very near dolomite equilibrium. This was tested by controlled laboratory studies (Roberts and others, 2004). These were designed as microcosms in which aquifer water was left sterile (abiotic controls) or in which the natural microorganisms from the field site were allowed to grow. Different minerals (basalt, calcite, and dolomite) were added to the microcosms as crushed $\mathrm{mm}$ size grains inside dialysis tubing to prevent direct colonization by microorganisms yet allow the minerals to affect the solution chemistry as they do in the natural situation. In the live experiments, microorganisms consumed hydrocarbons and produced $\mathrm{CO}_{2}$ while dissolving basalt near attached cells, releasing $\mathrm{Ca}, \mathrm{Mg}$, and $\mathrm{Si}$, compared to the sterile controls. The significantly higher dissolved silica in the live experiments compared to sterile controls supported a microbial role in basalt weathering. Evidence of basalt alteration with negligible dissolution of the dolomite and calcite in the dialysis tubing suggested that $\mathrm{Mg}$ and $\mathrm{Ca}$ are derived from the basalt rather than from carbonate phases. $\mathrm{CH}_{4}$ concentration increased significantly throughout the experiment indicating that methanogenesis was the predominant metabolic pathway. The release of $\mathrm{Ca}$ and $\mathrm{Mg}$ from basalt and the microbial consumption of $\mathrm{CO}_{2}$ resulted in the precipitation of carbonate minerals. The evidence from XRD and ESEM-EDS suggests that ordered dolomite and not ferroan dolomite precipitated in the laboratory microcosms.

Thus, in some microbially active systems, neither extremely $\mathrm{Mg}$-rich fluids nor highly supersaturated conditions are required for the nucleation and precipitation of dolomite. Microorganisms, either by their metabolic processes or owing to the nature of their cell surfaces directly influence the rate controlling step in dolomite precipitation. Here, methanogens and not sulfate reducing bacteria were found to be the principle organisms in dolomite nucleation and precipitation.

\section{Microbial Interaction with Silica}

At low temperature in most natural waters between $\mathrm{pH} 6$ to 10 , the dominant dissolved silica species is silicic acid, $\mathrm{Si}(\mathrm{OH})_{4}$. It is written in this way rather than in the more conventional $\mathrm{H}_{4} \mathrm{SiO}_{4}$ in order to emphasize that the metalloid $\mathrm{Si}$ tends to form hydroxo complexes, similar to metals (Stumm and Morgan, 1996). The rate of dissolution of crystalline silica (quartz) is so slow as to be negligible and follows the reaction:

$$
\mathrm{SiO}_{2}(\text { quartz })+2 \mathrm{H}_{2} \mathrm{O}=\mathrm{Si}(\mathrm{OH})_{4} \log \mathrm{K}=-3.7
$$


The rate of dissolution of amorphous (hydrated) Si is slightly higher:

$$
\mathrm{SiO}_{2} \text { (amorphous) }+2 \mathrm{H}_{2} \mathrm{O}=\mathrm{Si}(\mathrm{OH})_{4} \log \mathrm{K}=-2.7
$$

but is still very low in natural waters (Stumm and Morgan, 1996). However, these statements refer to the abiotic reactions. One of the greatest advances in knowledge of geomicrobiology in recent years has been in the area of interaction of microorganisms with silicate minerals (dissolution) and dissolved silica (mineral formation). What is beginning to emerge is a picture of how microorganisms are involved in a global cycling of silicon between the lithosphere and the biosphere and how they can mobilize and transfer silicon among different mineral phases (Schultze-Lam [Douglas] and others, 1995; Perry, 2003). In fact, it seems that microorganisms are a vital ingredient to a functioning global silicon cycle. The following sections will describe the current state of understanding and most recent experimental findings regarding interactions between microorganisms and silicate minerals. This will lead to a description of the ultimate expression of silicate mineralization, fossilized cells and silicate microbial fabrics.

Geomicrobiology of silicon in low temperature environments. - It is widely assumed that biogenic silica reaching the seabed is mostly subjected to simple dissolution, dehydration-crystallization, or burial and is not involved in complex mineral formation to any significant degree during early diagenesis (DeMaster and others, 1983; Ragueneau and others, 2000). One of the key studies outlining the significance of microbial involvement in silicon dynamics of a natural environment has recently shown that recycling of diatom frustules (fig. 6) is an important component of the silicon cycle, yet has been left out in previous studies. Michaelopoulos and Aller (2004) conducted a detailed study of Amazon River delta sediments as well as laboratory experiments, in order to elucidate the role of biogenic (that is, diatom) silica in the silica dynamics of this

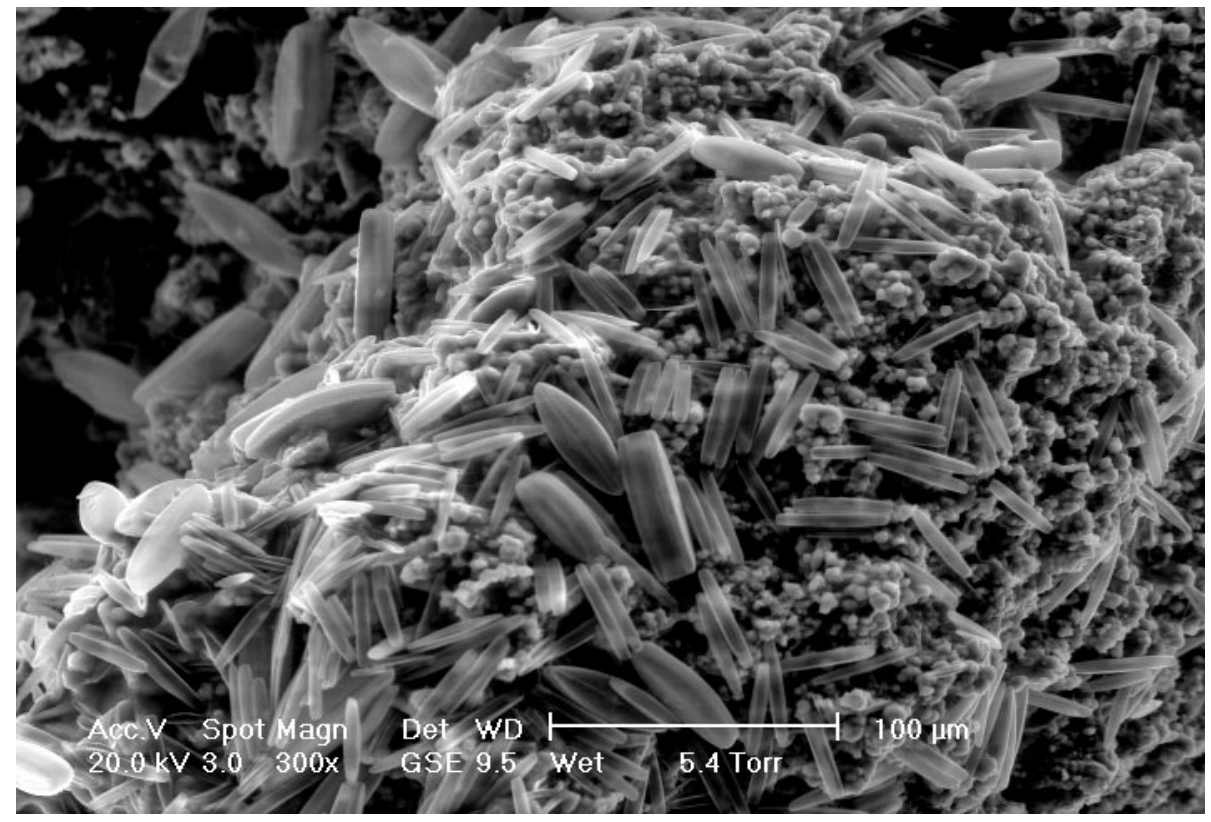

Fig. 6. ESEM image of diatoms as they appear in a natural biofilm from a fresh water environment. These elongated algal cells are encased in an intricate frustule of biogenic silica (opal). 
environment. Standard operational procedures designed to measure biogenic silica do not detect most diagenetic alteration products and substantially underestimate the quantity of reactive Si stored in the Amazon delta. Most ( 90\%) of the biogenic silica buried in Amazon River delta sediments is apparently converted to authigenic aluminosilicates, which are also responsible for the uptake of cations such as $\mathrm{K}$ and $\mathrm{Mg}$, and other elements such as $\mathrm{F}$, thus having a major influence on geochemistry in the Amazon delta (Michaelopoulos and Aller, 2004).

The Amazon delta sediments show a laminated structure in which a surface, "mobile" sediment overlies a dark brown to black layer. The mobile layer is rapidly turned over on time scales of months to years (Michalopoulos and Aller, 1996). Biogenic silica particles buried in suboxic Amazon delta deposits exist in various forms. In addition to relatively unaltered biogenic silica such as whole or corroded diatom frustules, there are: a) cation-rich aluminosilicate coatings on siliceous frustules and tests; and b) complete alteration of frustules to authigenic aluminosilicates, which are often rich in Fe and $\mathrm{K}$. Within the latter group, two subclasses can be identified: i) particles that comprise primarily authigenic aluminosilicate material locally replacing biogenic silica, and ii) composite pseudomorphs consisting of authigenic clay and agglutinated sedimentary matrix material (Michaelopoulos and Aller, 2004). Pyritefilled diatoms (framboids $\geq 10 \mu \mathrm{m}$ diameter) and diagenetic composite grains demonstrate that, upon deposition, diatom cells acted as microenvironments for sulfate reduction (Michaelopulos and Aller, 1996).

These observations of field samples were backed up by careful laboratory experiments. The alteration of biogenic silica and conversion to clays is a rapid process in the Amazon delta, with characteristic timescales of months to a few years. Experiments where cultured diatoms were inserted into unamended deltaic muds resulted, after 20 to 23 months, in complete conversion of frustules into a range of cation-rich silicates, including K-Fe-rich clay minerals (Michaelopoulos and others, 2000).

The lack of conclusive evidence for the formation of authigenic clay minerals in the past has resulted in the omission of such a process in the construction of the elemental cycle of Si on the Amazon shelf and elsewhere (DeMaster and others, 1983; Ragueneau and others, 2000). The operational analytical reactive Si pool represents a better estimate of the total quantity of biogenic $\mathrm{Si}$ and early diagenetic derivatives present in Amazon River delta sediments. Most alteration of Si occurs in the surface mobile zone, which acts functionally as a diagenetic batch reactor. The total accumulation of reactive $\mathrm{Si}$ is $\sim 1.7 \times 10^{11} \mathrm{~mol} \mathrm{Si} \mathrm{yr}^{-1}$ and represents $\sim 22$ percent of the estimated Amazon River input of $7.67 \times 10^{11}$ (DeMaster and Pope, 1996). Extrapolating the minimum trapping efficiency of the Amazon $(\sim 22 \%)$ estimated in this study to all tropical river systems yields a burial of $9.0 \times 10^{11}$ moles $\mathrm{yr}^{-1}, 2-3 \times$ that previously assumed and $\sim 15$ percent of global biogenic Si burial (Michaelopoulos and Aller, 2004).

Availability of reactive silica may limit or closely control clay formation in other deltaic systems as well. For example, in Mississippi Delta sediments, the occurrence of authigenic Fe-rich aluminosilicate (glauconite) has increased in surface sediments over the last $\sim 50 \mathrm{yr}$ of deposition (Nelsen and others, 1994). During the same period, the amount of biogenic silica stored in these sediments also increased due to increased supply of nutrients by the river and enhanced primary production in the coastal shelf waters due to eutrophication (Turner and Rabalais, 1994). The correlation between biogenic silica supply and the formation of green clays suggests that the two are linked. These inferences support the concept that deltaic depositional systems in general have the capacity for substantial conversion of biogenic silica and storage as derivative minerals. The factor that controls the degree of biogenic silica conversion is the ratio of biogenic silica to other limiting reactive constituents such as $\mathrm{Fe}$ and $\mathrm{Al}$. 
The actual mechanism of authigenic clay formation in this environment was not directly addressed; however what ingredients are present and what their sources may be were shown. The role of bacteria in clay formation was not discussed but from numerous other studies, it is likely that, in the Amazon Delta, as in other environments, bacteria play a pivotal role in the deposition of authigenic clays. In most environments, diatom cells are in close association with often epiphytic bacterial cells ( $\mathrm{S}$. Douglas, unpublished observations). Transmission electron microscopic (TEM) analyses of freshwater biofilms and bacterial cells, grown in experimental culture, have shown that these microorganisms are commonly associated with fine-grained $(\mathrm{Fe}, \mathrm{Al})$ silicates of variable composition (Konhauser and Urrutia, 1999). The inorganic phases develop in a predictable manner, beginning with the adsorption of cationic iron to anionic cellular surfaces. Supersaturation of the proximal fluid with $\mathrm{Fe}^{3+}$ is followed by nucleation and precipitation of a precursor ferric hydroxide phase on the cell surface. Finally, reaction with dissolved silica and aluminum results in the growth of an amorphous clay-like phase. Alternatively, colloidal species of ( $\mathrm{Fe}, \mathrm{Al})$ silicate composition may react directly with either the anionic cellular polymers or adsorbed iron, depending on their net charge (Warren and Ferris, 1998; Konhauser and others, 1998).

Experimental silicification studies.-Recent experimental studies have shown how bacteria can mediate the deposition of silicate minerals by acting as a nucleation site for the mineralization process. However, since at the $\mathrm{pH}$ of most natural waters $\mathrm{Si}$ is present as a negatively charged silicate anion, and the bacterial surface at these same $\mathrm{pH}$ levels tends to also be anionic (Konhauser and Urrutia, 1999), it has been proven that direct deposition of silicate minerals on bacterial cell surfaces requires the presence of a metal or metal containing phase such as $\mathrm{Fe}, \mathrm{Al}$ or ferrihydrite (Ferris, 1989; Walker and others, 1989; Urrutia and Beveridge, 1994). In nature, if soluble Si and heavy metals are available to bacteria, a number of mineral phases will be formed in time. The metals will complex to available organic sites on the bacterial surface and will, eventually, form mineral crystallites that are driven by the abundant counter ions to the mineralized metals in the surrounding fluid phase (for example, sulfates, carbonates, silicates, and oxyhydroxides). Over time, these hydrous precursors may dehydrate and convert to more stable crystalline phases (Konhauser and Urrutia, 1999; fig. 7). Because microbial biofilms are expansive and highly reactive surfaces at the sediment-water interface, coupled with their ability to bind soluble components and form solid inorganic phases, they should influence the chemical composition of the overlying aqueous microenvironment, and ultimately contribute to the makeup of river bottom sediment (Konhauser and others, 1993; Tazaki, 1997; Konhauser and others, 1998).

In natural hot spring waters silica $\left(\mathrm{SiO}_{2} \cdot \mathrm{nH}_{2} \mathrm{O}\right)$ is usually present in supersaturated conditions with respect to amorphous silica. However, recent studies have addressed the condition of undersaturation that prevails in most of the Earth's aqueous natural environments. Fein and others (2002) found that, in undersaturated solutions, there is little direct association between aqueous $\mathrm{Si}$ and the bacterial cell surface, even under low $\mathrm{pH}$ conditions where most of the organic functional groups that are present on the bacterial surface are fully protonated and neutrally charged. However, Fe and $\mathrm{Al}$ oxide coated bacteria, and Fe oxide precipitates only, all bound significant concentrations of aqueous $\mathrm{Si}$ over a wide range of $\mathrm{pH}$ conditions. They concluded that the association between silicate minerals and bacterial surfaces is not caused by direct Si-bacteria interactions, similar to the findings of earlier studies (Ferris, 1989; Walker and others, 1989). Rather, the association is most likely caused by the adsorption of $\mathrm{Si}$ onto $\mathrm{Fe}$ and $\mathrm{Al}$ oxides that are electrostatically bound to the bacterial cell surface. Therefore the role of bacteria in silica and silicate mineralization 


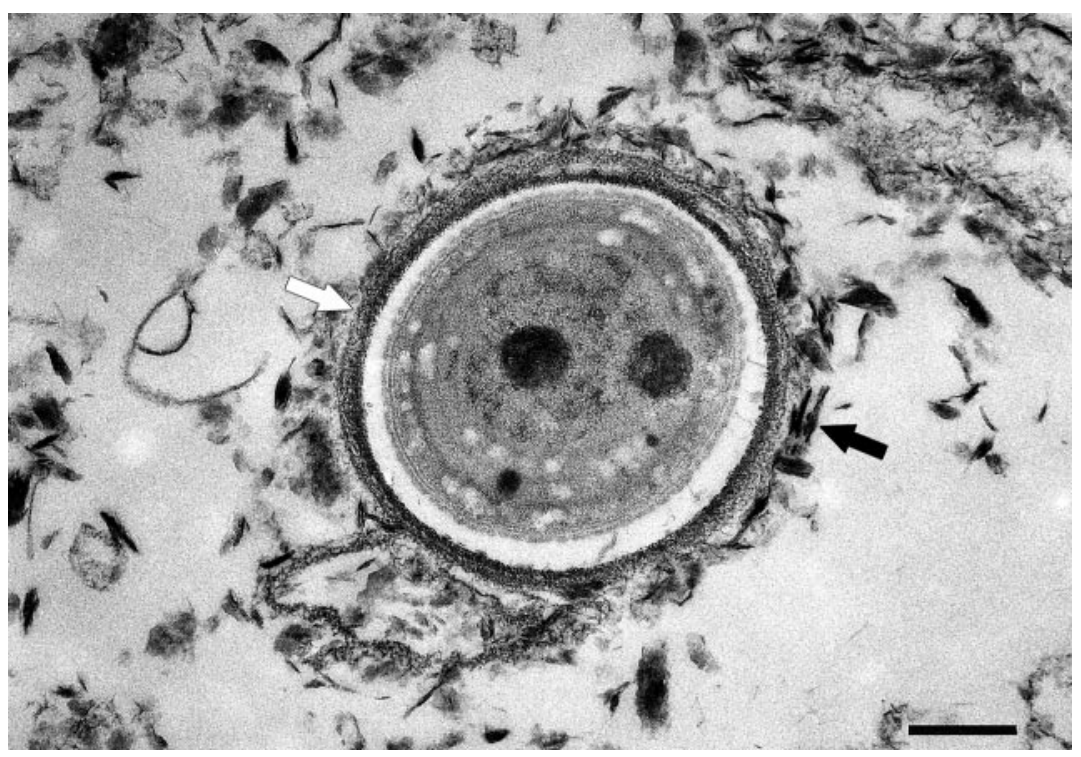

Fig. 7. Transmission electron micrograph of a stained, thin-sectioned cyanobacterium from a saline alkaline lake. The cell is surrounded by a sheath (white arrow) that is encased in a layer of small clay minerals (black arrow). Bar $=2 \mu \mathrm{m}$.

is to concentrate $\mathrm{Fe}$ and $\mathrm{Al}$ through adsorption and/or precipitation reactions (Warren and Ferris, 1998; Konhauser and others, 1998). Bacteria serve as bases or perhaps templates, for $\mathrm{Fe}$ and $\mathrm{Al}$ precipitation, and it is these oxide mineral surfaces (and perhaps other metal oxide surfaces as well) that are reactive with aqueous $\mathrm{Si}$, forming surface complexes that are the precursors to the formation of silica and silicate minerals.

The mechanism of silica-microbe interaction was further probed by a series of detailed studies using the cyanobacterium, Calothrix, a common constituent of biofilms in hydrothermal environments (Jones and others, 1998). This is a freshwater species that grows as a chain of cells within a thick polysaccharide sheath (fig. 8). The detailed structure of this type of cyanobacterium was described by Douglas (1998). The strain used in the silicification studies was isolated from a microbial community growing in a hot spring sinter, where the filaments showed a preferred vertical orientation and produced a distinct silicate fabric as they directed the depositional pattern of the amorphous silica from the hot spring water (Konhauser and others, 1999).

Cyanobacteria interact actively with a polymerizing silica solution, and this interaction can be monitored and quantified. Once the initial silica sorption stage is complete, the precipitation of amorphous silica will occur via an autocatalytic, abiogenic growth process, thus permitting the formation of silica-encrusted microorganisms as observed in many hot spring environments (fig. 9). Using a synchrotron-based structural and chemical technique, Benning and others (2004) showed that the reaction between live Calothrix cells and aqueous silica occurred predominantly on the surface of the sheath although the cell wall itself is considered by far the most reactive surface (that is, the sheath contains only $\sim 15$ percent of the total reactive functional groups on the surface of Calothrix and most functional groups are located upon the cell wall; Phoenix and others, 2002). In both whole cells and purified sheath, an increase in spectral intensity of the silica and carbohydrate bands was interpreted as a combination of increase in EPS sheath thickness followed by the silicification of the bacterial 


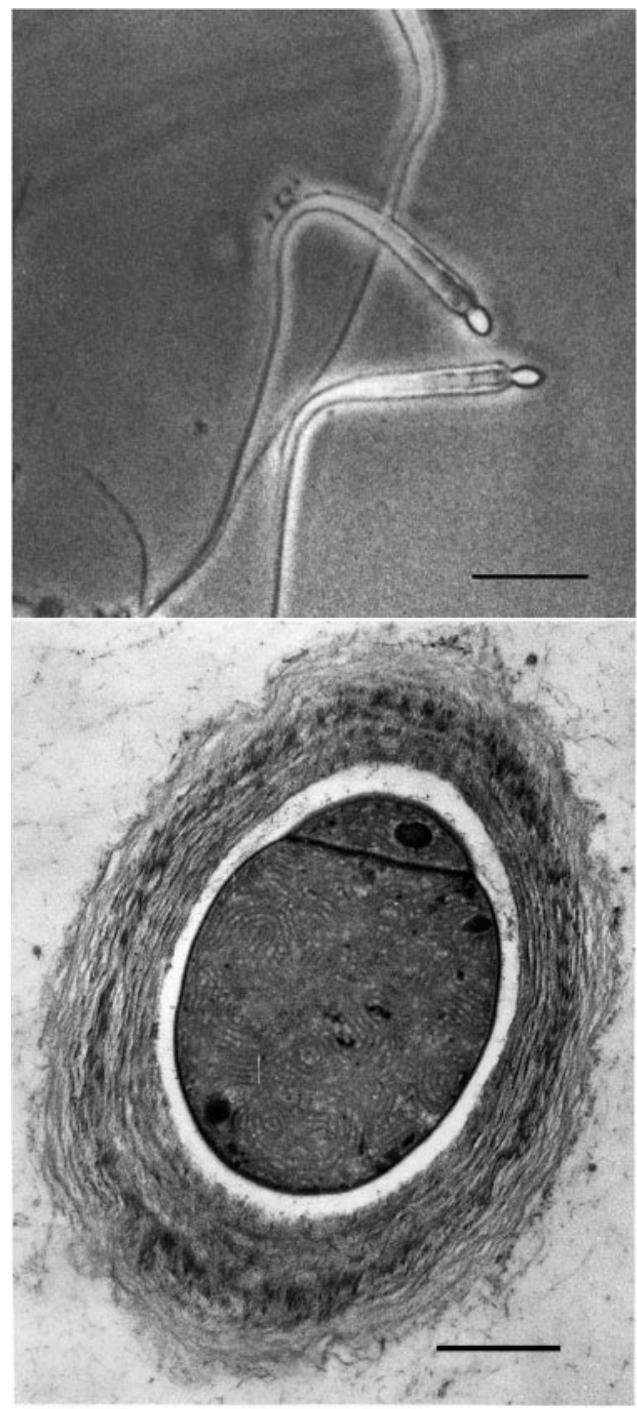

Fig. 8. The filamentous cyanobacterium, Calothrix. The upper image shows a light micrograph of these organisms. A single rounded heterocyst (special nitrogen-fixing cell) occupies the widest end of the tapering filament and is approximately $5 \mu \mathrm{m}$ in diameter $(\mathrm{Bar}=20 \mu \mathrm{m})$. The lower image shows a stained TEM thin section across a Calothrix filament. A white electron-translucent zone separates the cell wall and cell from the sheath. In this image the sheath appears as a concentric, fibrous layer forming the outermost structural layer of this organism. Bar $=2 \mu \mathrm{m}$.

filaments in response to the amorphous silica precipitation. These results corroborate the findings by Phoenix and others (2000), who suggested that the sheath may be necessary to provide the means for photosynthetically active cyanobacteria to survive mineralization. The sheath acts as the mineral deposition site, thus providing a physical barrier against colloidal silica deposition and preventing cell wall and/or cytoplasmic mineralization. This may also explain why the observed silicification of the sheath dominates over cell silicification.

Yee and others (2003) studied the actual mechanism of silica biomineralization with Calothrix for neutral $\mathrm{pH}$ experiments and Thiobacillus for low $\mathrm{pH}$ studies. The 


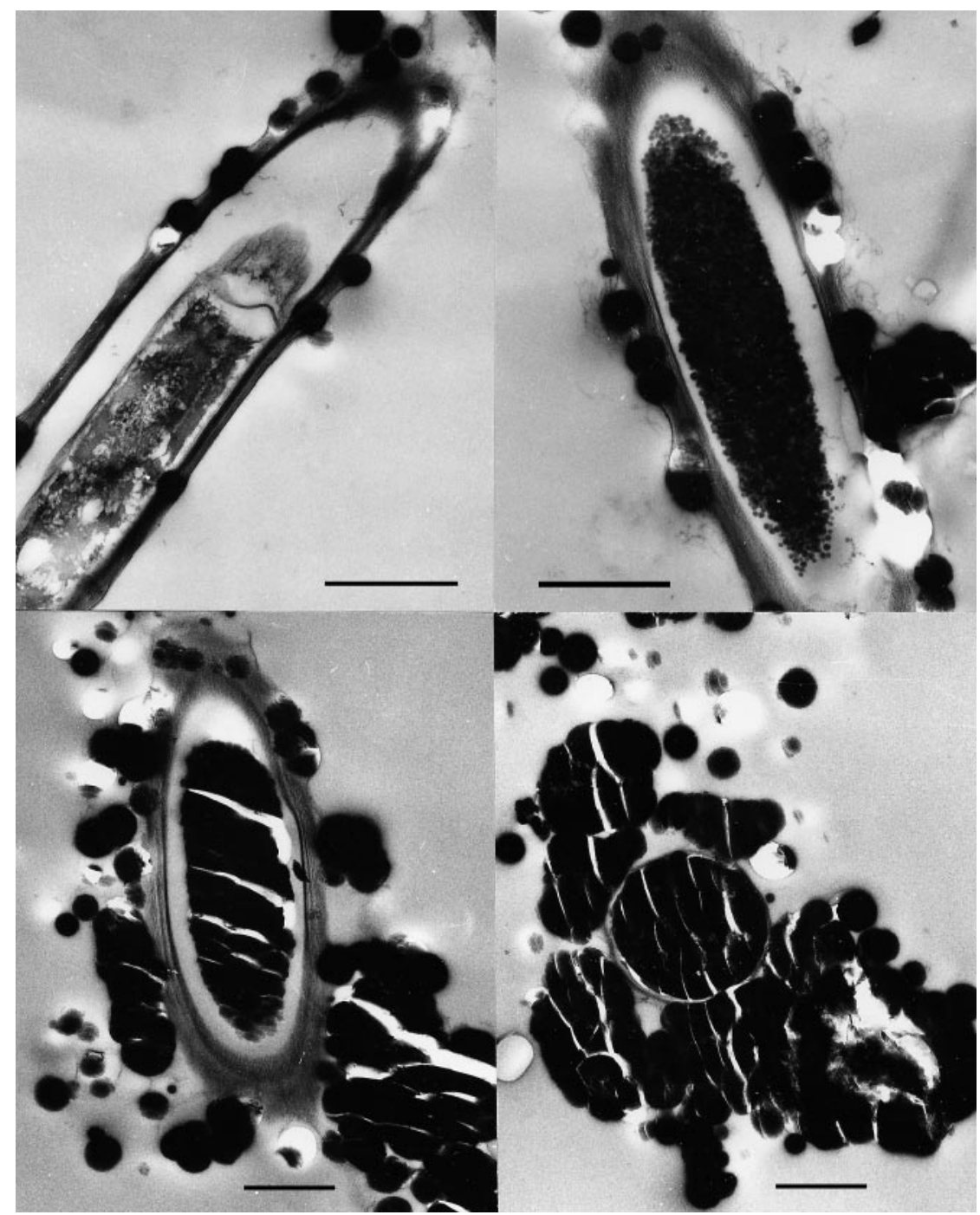

Fig. 9. A series of TEM images of unstained thin sections showing the progressive mineralization of a sheathed, filamentous organism from a natural hot spring microbial mat. The mineral is silica and is deposited in spherical, colloidal form until, eventually, in the bottom right image, only the sheath remains as a recognizable microbial feature. For all images, Bar $=2 \mu \mathrm{m}$.

effect of time, Si concentrations, temperature and ferrihydrite concentration was also investigated. In solutions supersaturated with respect to amorphous silica, direct binding of silicate anions and formation of silica aggregates by bacteria was most significant at low $\mathrm{pH}$, when polymerization of monosilicic acid $\left(\mathrm{H}_{4} \mathrm{SiO}_{4}\right)$ is slow and kinetic activation energy barriers inhibit silica nucleation (Fortin and others, 1996). They demonstrated that the presence of Thiobacillus promoted rapid formation of amorphous silica at low $\mathrm{pH}$ values, while an abiotic system with the same chemical conditions did not allow silica precipitation. Therefore in acidic conditions, bacteria act as a reactive interface that facilitates heterogeneous nucleation and enhances the precipitation kinetics. 
At $\mathrm{pH} 7.0$, monomeric $\mathrm{Si}$ can polymerize to form silica colloids $(1-100 \mathrm{~nm}$ in diameter) and the polymerization reaction rapidly decreases the concentration of soluble $\mathrm{Si}$ in solution (Rinehart, 1980). At the same $\mathrm{pH}$, the Calothrix cell surface contains both protonated and deprotonated carboxyl, phosphoryl, and amine functional groups (Phoenix and others, 2002). Yee and others (2003) showed that the interaction between $\mathrm{Si}$ and these surface functional groups is weak. At under saturated conditions the stability of a silicic acid-Calothrix surface complex is very low. This is consistent with the findings by Fein and others (2002) who demonstrated that dilute concentrations of aqueous $\mathrm{Si}$ do not readily sorb onto bacterial cell walls. However, silica precipitation experiments conducted with ferrihydrite-coated cyanobacteria indicated that the presence of ferrihydrite surfaces significantly increased the rate and extent of Si removal from solution (Yee and others, 2003). Increasing the amount of ferrihydrite coating on the cell surface increased the rate and amount of silica sorbed from solution.

\section{Silicified Microbial Mats in Natural Environments: Wrinkle Structures}

Sedimentary structures mediated by microbes are well known from carbonate depositional settings yet, relatively little is known about microbial sedimentary structures that are produced in siliciclastic sedimentary environments. This section highlights the recently begun investigations of microbially created and mediated siliciclastic sedimentary structures. Like ancient stromatolites, these structures are perhaps best preserved before the Phanerozoic advent of extensive bioturbation. Like stromatolites, they are also common in stressed Phanerozoic and modern marine environments.

Wrinkle structures are a type of microbially mediated sedimentary structure found preserved in siliciclastic deposits (Hagadorn and Bottjer, 1997). The formation of these structures has been attributed to the stabilization of the substrate by microbial mats (Hagadorn and Bottjer, 1997, 1999; Noffke and Krumbein, 1999; Noffke, 2000; Noffke and others, 2001, 2002, 2003). Gerdes and others (1985) used the term Petee structure for biogneic wrinkles and table cloth folds in contrast to the inorganic mud crack systems named Tepee structures. They are common sedimentary features in Proterozoic-Cambrian strata (for example, Hagadorn and Bottjer, 1997) although their record has been found to extend back to the Middle Archaean (Noffke and others, 2003). Wrinkle structures were originally interpreted as sedimentary structures produced by physical current waning, wind-induced shear, mud cracking and sediment loading (for example, Allen, 1985) but are now known to be the preserved remains of a microbial mat community (Hagadorn and Bottjer, 1997). The fact that almost any sedimentary surface today, even the bottom of rain puddles, is soon colonized by an overlying, cohesive "skin" of microorganisms, implies that such formations should also have been present in some form or other in Earth's past history (Noffke and others, 2003). A time period to focus on for finding microbial matinduced structures would be prior to the advent of metazoans and their bioturbation activities (that is, Cambrian and pre-Cambrian times).

Microbial mats in modern siliciclastic environments consist of a variety of microbial cell types and extracellular polymeric substances. Due to the combined presence of filamentous microorganisms (mainly cyanobacteria and/or sulfide oxidizing bacteria) and EPS, well formed microbial mats have a very robust and cohesive structure; significant force is required to pull them apart. Wave and current interaction with these structures is recorded as microbially induced sedimentary structures (Noffke and others, 2001). A number of key morphological characteristics have been defined by Gerdes and Krumbein (1987) and Schieber (1999) to allow identification of lithified (ancient) versions of these structures in the field. Among these, the most easily recognizable are irregular, wrinkled bedding plane surfaces, laminae with mica enrichment, and ripple patches on bedding planes in sedimentary rocks. 
Another clue to the former presence of microbial mats is that they produce sharp geochemical boundaries in sediments and thus sharp mineralogical boundaries in sedimentary rocks such as sandstone (Bauld, 1981). Due to anaerobic decay of mat microorganisms chemical conditions beneath modern mats in sandy sediments tend to be strongly reducing (Bauld, 1981; Gerdes and others, 1985). In fact, conditions can go from highly oxic (due to photosynthetic activity) to completely anoxic within millimeters. This may lead to formation of "anoxic" indicator minerals beneath the mat (for example, pyrite, siderite, ferroan dolomite), although the mat surface itself is in contact with oxygen-bearing waters (Gerdes and others, 1985). The cementation of sand grains by these minerals can be considered a "mat-decay mineralization." Welldefined, thin layers of these minerals in a shallow-water sandstone may be a clue to the former presence of microbial mats (Gerdes and others, 1985; Garlick, 1988).

\section{Microfossils}

The culmination of the interaction of microorganisms with metals and minerals is the formation of "mineral casts" or replicas of the microbial structure (that is, microfossils). This is where the line between geology and biology really becomes blurred (see fig. 9). Often, structures reported to be microfossils have been proven later to be attributable to geological, abiotic formative mechanisms. However, their true nature remained in doubt. Why should we care about microfossils? Because they represent one of the earliest evidences for life from a time (billions of years ago) when microorganisms were the only life forms on the planet. Given their profound effect on modern day geochemistry, ecology, and their ubiquitous presence, it is reasonable to assume that, at a time when microorganisms were the only life form present on the planet, they must have had a great impact on the shaping of the biosphere.

What is a microfossil? How do we recognize it? A combination of chemistry, morphology, and geological provenance must together give evidence supporting the presence of a biological structure. With the advent of new techniques it is possible to overcome some of the difficulties inherent in the study and identification of microfossils as bona fide biological structures. The ability to link biogenic signals to individual microfossil structures will help unambiguously assess the biological nature of ancient microfossils. Modern examples of microbial deposition of amorphous silica (opal) exist, pointing to possible mechanisms for microfossil formation. Opal may replace microbial structures (Schultze-Lam and others, 1995), leaving behind a mineral cast of the former organism. It may also be deposited in layered microbial communities so that opal stromatolite may be formed (Gorbushina and others, 2001).

One of the most effective methods developed to examine microbial communities, living and fossilized, plus all the stages in between in the context of its geological surroundings is electron microscopy in combination with the microanalytical technique of energy dispersive xray spectroscopy(EDS). Ascaso and Wierzchos (1994) were the first to pioneer the combination of backscattered electron imaging and EDS on embedded and polished samples in order to ascertain not only the presence of microbial communities and associated minerals, but even the internal ultrastructure of the cells. This was a breakthrough in our ability to understand the inter-relationship of microorganisms and minerals in natural environments. Through studies of endolithic microbial communities from the Antarctic Dry Valleys, it was ascertained that the layered fungal $p$ photobiont protolichen communities that inhabit these rocks (quartzite, granite, or marble) promoted the deposition of pericellular minerals (Fe, Al-rich clays, iron oxides, and jarosite) and eventually were preserved as mineral replicas (Wierzchos and Ascaso, 2001, 2002; Wierzchos and others, 2003, 2004).

New approaches to microfossil studies; examination of individual microorganisms. - In order to understand some of the processes involved in the formation of microfossils, new techniques allowing the chemical examination of indiviual microbial cells or 
filaments offer new insight, providing complementary information to the study of microbial communities as discussed above. Synchrotron based and PIXE (protoninduced X-ray emission) techniques allow high resolution and nondestructive chemical imaging of micron scale objects embedded in complex geological matrices (Philippot and others, 2000, 2001; Menez and others, 2002; Foriel and others, 2003). The results obtained by SXRF (sunchrotron based xray fine structure) and PIXE demonstrate, first, that these techniques are suitable for determining the trace element distribution on the scale of an individual microbial filament, and, second, that an internal element signal remains in the silicified fossils that can be reasonably attributed to a microbially derived origin and not to contamination, as indicated by the differential distribution of transition metals in the fossil core. Foriel and others (2003) examined both live microbial filaments and microfosssil filaments on a single filament basis in order to determine what elemental content and distribution differences may exist between the two. The distribution of $\mathrm{Fe}, \mathrm{Cu}$, and $\mathrm{Zn}$ in the internal area of the opal structure once occupied by a bacterial filament suggested that it contained these elements and/or induced their precipitation on its cell surface (Fortin and others, 1997) either during its lifetime or during the fossilization process. Fe, $\mathrm{Cu}$, and $\mathrm{Zn}$ can be used as cofactors by living cells, and Fe-based microbial metabolisms are important in hydrothermal regions. For example, several deep-sea vent species are able to reduce $\mathrm{Fe}$ (III), while others can oxidize Fe(II), forming iron oxide crusts (Emerson and Moyer, 2002). Therefore it is reasonable to find these elements in the internal regions of the filament and they were also present in the living filament used in this study. A more sensitive technique, SXRF (synchrotron x-ray micorfluorescence), was able to provide further information on trace element distribution in individual bacterial filaments and microfossils (Foriel and others, 2003, 2004). In both the living bacterial filaments and the microfossil this technique revealed the presence of $\mathrm{S}, \mathrm{Cl}, \mathrm{K}, \mathrm{Ca}, \mathrm{Mn}$, $\mathrm{Fe}, \mathrm{Cu}, \mathrm{Zn}, \mathrm{Pb}, \mathrm{Br}$, and $\mathrm{Sr}$. However, elements attributable to contamination by sea water $(\mathrm{S}, \mathrm{Cl}, \mathrm{Ca}, \mathrm{Br}, \mathrm{Sr}$ ) were present only in the outer (sheath) layers of the living filament and the microfossil.

A third technique, micro-XANES (micro-x-ray absorption near-edge structure) conducted as part of the same study, represented the first chemical imaging of sulfur oxidation states in microbial filaments, revealing the distribution of sulfur in a range of redox states (Foriel, 2003; Foriel and others, 2004). In the same filaments studied by the previously described techniques, the organic sulfur signal overlapped signals for $\mathrm{N}-\mathrm{H}$ and $\mathrm{C}-\mathrm{H}$ groups, furthering the notion that the sulfur was biogenic as it was clearly covalently bonded to organic molecules. Overall, recognition that the C-H groups (and amide) for the bacterial filament maps overlay sulfur distribution of the living bacterial filament further supports the interpretation that the sulfur signal is of biogenic origin. The sulfur redox distribution coupled with the $\mathrm{C}-\mathrm{H}$ group signal are not limited to the bacterial filament but are also found in the filamentous microfossils. These observations demonstrated that filamentous Fe-bearing microstructures embedded in silica from an inactive hydrothermal chimney are of biogenic origin.

CONCLUDING REMARKS

This paper has barely scraped the surface of the knowledge available regarding microbiological involvement in shaping geology. However, it has hopefully given a flavor of the breadth and diversity of microbe-mineral interactions.

\section{ACKNOWLEDGMENTS}

All figures were from the author's laboratory based on research funded by the National Aeronautics and Space Administration and the Jet Propulsion Laboratory.

I would like to thank W. E. Krumbein, C. Vasconcelos, and J. Wierzchos for the time they spent to provide very thorough reviews of this paper. Their comments helped 
me make immeasurable improvements. I would also like to thank Dr. Pamela Conrad for her continued encouragement and support as we delve into the world of microbes and minerals together.

\section{REFERENCES}

Allen, J. R. L., 1985, Wrinkle marks: an intertidal sedimentary structure due to aseismic soft sediment loading: Sedimentary Geology, v. 41, p. 75-95.

Andreychuk, V. N., and Klimchouk, A. B., 2001, Geomicrobiology and redox chemistry of the karstified miocene gypsum aquifer, Western Ukraine: the study from Zoloushka Cave: Geomicrobiology Journal, v. 18 , p. $275-295$.

Ascaso, C., and Wierzchos, J., 1994, Structural aspects of the lichen-rock interface using backscattered electron imaging: Botanica Acta, v. 107, p. 251-256.

Bauld, J., 1981, Geobiological role of cyanobacterial mats in sedimentary environments: production and preservation of organic matter: BMR Journal of Australian Geology and Geophysics, v. 6, p. 307317.

Bekins, B. A., Godsy, E. M., and Warren, E., 1999, Distribution of microbial types in an aquifer contaminated by crude oil: Microbial Ecology, v. 37, p. 263-275.

Bennett, P. C., Rogers, J. R., Hiebert, F. K., and Choi, W. J., 2001, Silicates, silicate weathering, and microbial ecology: Geomicorbiology Journal, v. 18, p. 3-19.

Benning, L. G., Phoenix, V. R., Yee, N., and Tobin, M. J., 2004, Molecular characterization of cyanobacterial silicification using synchrotron infrared micro-spectroscopy: Geochimica et Cosmochimica Acta, v. 68, p. 729-741.

Beveridge, T. J., 1981, Ultrastructure, chemistry and function of the bacterial cell wall: International Review of Cytololgy, v. 72, p. 229-317.

Beveridge, T. J., and Fyfe, W. S., 1985, Metal fixation by bacterial cell walls: Canadian Journal of Earth Sciences, v. 22, p. 1893-1898.

Burne, R. V., and Moore, L. S., 1987, Microbialites, Organosedimentary deposits of benthic microbial communities: Palaios, v. 2, p. 241-254.

Burns, S. J., McKenzie, J. A., and Vasconcelos, C., 2000, Dolomite formation and biogeochemical cycles in the Phanerozoic: Sedimentology, v. 47, p. 49-61.

Cañaveras, J. C., Sanchez-Moral, S., Soler, V., and Saiz-Jimenez, C., 2001, Microorganisms and microbially induced cave fabrics: Geomicrobiology Journal, v. 18, p. 223-240.

Capo, R. C., Whipkey, C. E., Blachere, J. R., and Chadwick, O. A., 2000, Pedogenic origin of dolomite in a basaltic weathering profile, Kophala Peninsula, Hawaii: Geology, v. 28, p. 271-274.

Carballo, J. D., Land, L. S., and Miser, D. E., 1987, Dolomitization of supratidal sediments by active tidal pumping, Sugarloaf Key, Florida: Journal of Sedimentary Petrology, v. 57, p. 153-165.

Cox, G., James, J. M., Leggett, K. E. A., and Osborne, R. A. L., 1989, Cyanobacterially deposited speleothems: subaerial stromatolites: Geomicrobiology Journal, v. 7, p. 245-252.

De Master, D. J., and Pope, R. H., 1996, Nutrient dynamics in Amazon shelf waters: results from AMASSEDS: Continental Shelf Research, v. 16, p. 263-289.

DeMaster, D. J., Knapp, G. B., and Nitrouer, C. A., 1983, Biological uptake and accumulation of silica on the Amazonian continental shelf: Geochimica et Cosmochimica Acta, v. 47, p. 1713-1723.

Douglas, S., 1998, Effects of alkaline earth metal ions on the growth of Calothrix strain RC3, a natural isolate from Rock Creek, British Columbia: Canadian Journal of Microbiology, v. 44, p. 128-139.

Douglas, S., and Beveridge, T. J., 1998, Mineral formation by bacteria in natural microbial communities: FEMS Microbiology Ecology, v. 26, p. 79-88.

Douglas, S., and Douglas, D. D., 2000, Environmental scanning electron microscopy studies of colloidal sulfur deposition in a natural microbial community from a cold sulfide sparing near Ancaster, Ontario, Canada: Geomicrobiology Journal, v. 17, p. 275-289.

_ 2001, Structural and geomicrobiological characteristics of a microbial community form a cold sulfide spring: Geomicrobiology Journal, v. 18, p. 401-422.

Douglas, S., and Yang, H., 2002, Mineral biosignatures in evaporites: presence of rosickyite in an endoevaporitic microbial community from Death Valley, California: Geology, v. 30, p. 1075-1078.

Ehrlich, H. L., 1996, Geomicrobiology, $3^{\text {rd }}$ edition: New York, Marcel Dekker, 718 p. 1999, Microbes as geologic agents: their role in mineral formation: Geomicrobiology Journal, v. 16, p. 135-153.

Emerson, D., and Moyer, C. L., 2002, Neutrophilic, Fe-oxidizing bacteria are abundant at the Loihi seamount hydrothermal vents and play a major role in Fe oxide deposition: Applied and Environmental Microbiology, v. 69, p. 3085-3093.

Engel, A. S., Stern, L., and Bennett, P. C., 2004, Microbial contributions to cave formation: new insights into sulfuric acid speleogenesis: Geology, v. 32, p. 369-372.

Evans, G., Schnidt, V., Bush, P., and Nelson, H., 1969, Stratigraphy and history of the sabhka, Abu Dhabi, Persian Gulf: Sedimentology, v. 12, p. 145-159.

Fein, J. B., Scott, S., and Rivera, N., 2002, The effect of iron on Si adsorption by Bacillus subtilis cell walls: insights into non-metabolic bacterial precipitation of clay minerals: Chemical Geology, v. 182, p. 265273.

Ferris, F. G., 1989, Metallic ion interactions with the outer membrane of Gram-negative bacteria, in Beveridge, T. J., and Doyle, R. J., editors, Metal Ions and Bacteria: New York, Wiley, p. 295-323. 
Foriel, J., Philippot, P., Ménez, B, Simionovici, A., and Bohic, S., 2003, Trace element content and distribution in a single fluid inclusion from Dunbar Oil Field, North Sea: Journal of Physics IV, v. 104, p. 385-390.

Foriel, J., Philippot, P., Susini, J., Dumas, P., Somogyi, A., Salome, M., Khodia, H., Menez, B., Fouquet, Y., Moreira, D., and Lopea-Garcia, P., 2004, High-resolution imaging of sulfur oxidation states, trace elements, and organic molecules distribution in individual microfossils and contemporary microbial filaments: Geochimica et Cosmochimica Acta, v. 68, p. 1561-1569.

Fortin, D., and Beveridge, T. J., 1997, Microbial sulfate reduction withim sulfidic mine tailings, formation of diagentic Fe-sulfides: Geomicrobiology Journal, v. 14, p. 1-21.

Fortin, D., Davis, B., Southam, G., and Beveridge, T. J., 1995, Biogeochemical phenonmena induced by bacteria within sulfidic mine tailings: Journal of Industrial Microbiology, v. 14, p. 178-185.

Fortin, D., Davis, B., and Beveridge, T. J., 1996, Role of Thiobacillus and sulfate reducing bacteria in iron biocycling in oxic and acidic mine tailings: FEMS Microbiology Ecology, v. 21, p. 11-24.

Fortin, D., Ferris, F. G., and Beveridge, T. J., 1997, Surface mediated mineral development by bacteria, in Banfield, J. F., and Nealson, K. H., editors, Geomicrobiology: Interactions Between Microbes and Minerals: Washington, D. C., Mineralogical Society of America, Reviews in Mineralogy, v. 35, p. 161180.

Frankel, R. B., and Bazylinski, D. A., 2003, Biologically induced mineralization by bacteria, in Dove, P. M., De Yoreo, J. J., and Weiner, S., Biomineralization: Reviews in Mineralogy and Geochemistry, v. 54, p. $95-114$

Garlick, W. G., 1988, Algal mats, load structures, and synsedimentary sulfides in Revett quartzites of Montana and Idaho: Economic Geology, v. 83, p. 1259-1278.

Geesey, G. G., Jang, L., Jolley, J. G., Hankins, M. R., Iwaoka, T., and Griffiths, P. R., 1988, Binding of metal ions by extracellular polymers of biofilm bacteria: Water Science and Technology, v. 20, p. 161-165.

Gerdes, G., Krumbein, W. E., and Reineck, H. E., 1985, The depositional record of sandy, versicolored tidal flats (mellum Island, southern North Sea): Journal of Sedimentary Petrology, v. 55, p. 265-278.

Gerdes, G., Klenke, T., and Noffke, N., 2000, Microbial signatures in peritidal siliciclastic sediments: a catalogue: Sedimentology, v. 47, p. 279-308.

Gorbushina, A. A., Boettcher, M., Brumsack, H. J., Krumbein, W. E., and Vendrell-Saz, M., 2001, Biogenic forsterite and opal as a product of bioseterioration and lichen stromatolite formation in table mountain systems (Tepuis) of Venezuela: Geomicrobiology Journal, v. 18, p. 117-132.

Hagadorn, J. W., and Bottjer, D. J., 1997, Wrinkle structures: microbially mediated sedimentary structures common in subtidal silicilastic settings at the Proterozoic-Phanerozoic transition: Geology, v. 25, p. 1047-1050.

1999, Restriction of a late Neoproterozoic biotope: suspect microbial structures at the VendianCambrian transition: Palaois, v. 14, p. 73-85.

Hill, C. A., and Forti, P., 1997, Cave Minerals of the World, $2^{\text {nd }}$ Edition: Huntsville, Alabama, National Speleological Society, $463 \mathrm{p}$.

Jones, B., Renaut, R. W., and Rosen, M. R., 1998, Microbial biofacies in hot spring sinters: a model based on Ohaaki Pool, North Island, New Zealand: Journal of Sedimentary Research, v. 68, p. 413-434

Jorgensen, B. B., Bottcher, M. E., and Luschen, H., 2004, Anaerobic methane oxidation and a deep $\mathrm{H}_{2} \mathrm{~S}$ sink generate isotopically heavy sulfides in Black Sea sediments: Geochimica et Cosmochimica Acta, v. 68, p. 2095-2118.

Kempe, S., Kazierczak, J., Landmann, G., Koruk, T., and Reimer, A., 1991, Largest known microbialites discovered in Lake Van, Turkey: Nature, v. 349, p. 605-608.

Kennard, J. M., and James, N. P., 1986, Thrombolites and stromatolites, two distinct types of microbial structures: Palaios, v. 1, p. 492-503.

Konhauser, K. O., and Urrutia, M. M., 1999, Bacterial clay authigenisis: a common biogeochemical process: Chemical Geology, v. 161, p. 399-413.

Konhauser, K. O., Fyfe, W. S., Ferris, F. G., and Beveridge, T. J., 1993, Metal sorption and mineral precipitation by bacteria in two Amazonian River sytems: Rio Solimoes and Rio Negro, Brazil: Geology, v. 21, p. 1103-1106.

Konhauser, K. O., Fisher, Q. J., Fyfe, W. S., Longstaffe, F. J., and Powell, M. A., 1998, Authigenic mineralization and detrital clay binding by freshwater biofilms: the Brahmani River, India: Geomicrobiology Journal, v. 15, p. 209-222.

Konhauser, K. O., Phoenix, V. R., Bottrell, S. H., Adams, D. G., and Head, I. M., 1999, Microbial silica interactions in modern hot spring sinter, in Armannsson, H., editor, Geochemistry of the Earth's Surface: Balkema, Rotterdam, p. 263-266.

Krumbein, W. E., Cohen, Y., and Shilo, M., 1977, Solar lake, Sinai 4. Stromatolitic cyanobacterial mats: Limnology and Oceanography, v. 22, p. 635-656.

Krumbein, W.E., Brehm, U., Gerdes, G., Gorbushina, A. A., Levit, G., and Palinska, K. A., 2003, Biofilm, Biodictyon, and Biomat-Biolaminites, Oolites, Stromatolites-Geophysiology, Global mechanisms, and Parahistology, in Krumbein, W. E., Paterson, D. W., and Zavarzin, G. A., editors, Fossil and Recent Biofilms, a natural histroy of life on Earth: Dordecht, Kluwer Academic Publishers, p. 1-28.

Little, B. J., Wagner, P. A., and Lewandowski, Z., 1997, Spatial relationships between bacteria and mineral surface, in Banfield, J. F., and Nealson, K. H., editors, Geomicrobiology: Interactions Between Microbes and Minerals: Washington, D. C., Mineralogical Society of America, Reviews in Mineralogy, v. 35, p. 123-159.

MacKenzie, F. T., and Morse, J. W., 1992, Sedimentary carbonate through Phanerozoic time: Geochimica et Cosmochimica Acta, v. 56, p. 3281-3295. 
McKenzie, J. A., Hsu, K. J., and Schneider, J. F., 1980, Movement of subsurface waters under the sabkha, Abu Dhabi, UAE, and its relation to evaporative dolomit genesis, in Zenger, D. H., editor, Concepts and Models of Dolomitization: Society of Economic Paleontologists and Mineralogists, v. 28, p. 11-30.

Meisser, N., Schenk, K. J., and Spangenburg, J. E., 2000, Rosickyite (monoclinic $\gamma$-sulfur) from La Presta asphalt mine, Neuchâtel, Switzerland: new X-ray powder diffraction data: Schweizerisches Mineralogisches und Petrographisches Mitteilung, v. 80, p. 299-303.

Menez, B., Philippot, P., Bonnin-Mosbah, M., Simionovici, A., and Gilbert, F., 2002, Analysis of individual fluid inclusions using synchrotron x-ray fluorescence microprobe: progress toward calibration for trace elements: Geochimica et Cosmochimica Acta, v. 66, p. 562-576.

Michaelopoulos, P., and Aller, R. C., 1996, Early diagenetic carbon minerals in Amazon delta sediments: controls by depositional regime on formation, mineralogy, and composition: Geological Society of America Abstracts, p. 90.

2004, Early diagenisis of biogenic silica in the Amazon delta: alteration, authigenic clay formation and storage: Geochimica et Cosmochimica Acta, v. 68, p. 1061-1085.

Michaelopoulos, P., Aller, R. C., and Reeder, R. J., 2000, Conversion of diatoms to clays during early diagenisis in tropical, continental shelf muds: Geology, v. 28, p. 1095-1098.

Moore, G. W., 1952, Speleothem-a new cave term: National Speleological Society News, v. 10, p. 2.

Moreira, N. F., Walter, L. M., Vasconcelos, C., McKenzie, J. A., and McCall, P. J., 2004, Role of sulfide oxidation in dolomitization: Sediment and pore-water geochemistry of a modern hypersaline lagoon system: Geology, v. 32, p. 701-704.

Mozely, P. S., and Burns, S. J., 1993, Oxygen and carbon isotopic composition of marine carbonate concretions: an overview: Journal of Sedimentary Petrology, v. 63, p. 73-83.

Nelsen, T. A., Blackwelder, P., Hood, T., McKee, B., Romer, N., Alvarez, P., Zarikian, C., and Metz, S., 1994, Time-based correlation of biogenic, lithogenic, and authigenic sediment components with anthropogenic inputs in the Gulf of Mexico NECOP study area: Estuaries, v. 17, p. 873-885.

Noffke, N., 2000, Extensive microbial mats and their influences on the erosional and depositional dynamics of a siliciclastic cold water environment (Lower Arenigian, Montagne Noire, France): Sedimentary Geology, v. 136, p. 207-215.

Noffke, N., and Krumbein, W. E., 1999, A quantitative approach to sedimentary surface structures contoured by the interplay of microbial colonization and physical dynamics: Sedimentology, v. 46, p. 417-426.

Noffke, N., Gerdes, G., Klenke, T., and Krumbein, W. E., 2001, Microbially induced sedimentary structures-a new category within the classification of primary sedimentary structures: Journal of Sedimentary Research, v. 71, p. 646-656.

Noffke, N., Knoll, A. H., and Grotzinger, J. P., 2002, Sedimentary controls on the formation and preservation of microbial mats in siliciclastic deposits: a case study from the Upper Neoproterozoic Nama Group, Namibia: Palaois, v. 17, p. 533-544.

Noffke, N., Hazen, R., and Nhleko, N., 2003, Earth's earliest microbial mats in a siliciclastic marine environment (2.9 Ga Mozaan Group, South Africa): Geology, v. 31, p. 673-676.

Northup, D. E., and Lavoie, K. H., 2001, Geomicrobiology of caves: a review: Geomicrobiology Journal, v. 18, p. 199-222.

Pentecost, A., 1987, Growth and calcification of the freshwater cyanobacterium Rivularia haematites: Proceedings of the Royal Society of London B, v. 232, p. 125-136.

1988, Growth and calcification of the cyanobacterium Homeothrix crustacea: Journal of General Microbiology, v. 134, p. 2665-2671.

Perry, C. C., 2003, Silicification: The processes by which organisms capture and mineralize silica, in Dove, P. M., De Yoreo, J. J., and Weiner, S., Biomineralization: Reviews in Mineralogy and Geochemistry, v. 54, p. 291-327.

Philippot, P., Menez, B., Simionovici, A., Chabiron, A., Cuncy, M., Snigrev, A., and Snigreva, I., 2000, X-ray imaging of uranium in individual fluid inclusions: Terra Nova, v. 12, p. 84-89.

Philippot, P., Menez, B., Drakopoulos, M., Simionovici, A., Snigrev, A., and Snigreva, I., 2001, Mapping trace metal ( $\mathrm{Cu}, \mathrm{Zn}$, As) distribution in a single fluid inclusion using a third generation synchrotron light source: Chemical Geology, v. 173, p. 151-158.

Phoenix, V. R., Adams, D. G., and Konhauser, K. O., 2000, Cyanobacterial viability during hydrothermal biomineralization: Chemical Geology, v. 169, p. 329-338.

Phoenix, V. R., Martinez, R. E., Konhauser, K. O., and Ferris, F. G., 2002, Characterization and implications of the cell surface reactivity of the cyanobacterium Calothrix KC97: Applied and Environmental Microbiology, v. 68, p. 4827-4834.

Pochon, M. J., Chalvignac, M. A., and Krumbein, W. E., 1964, Recherches biologiques sur le mondmilch: Paris, Transactions of the Academic Sciences, v. 258, p. 5113-5115.

Potts, M., 1994, Dessication tolerance of prokaryotes: Microbiological Reviews, v. 58, p. 755-805.

Provencio, P. P., and Polyak, V. J., 2001: Iron-oxide-rich filaments: Possible fossil bacteria in Lechuguilla Cave, New Mexico: Geomicrobiology Journal, v. 18, p. 297-309.

Ragueneau, O., Treguer, P., Leynaert, A., Anderson, R. F., Vrezinski, M. A., DeMaster, D. J., Dugdale, R. C., Dymond, J., Fischer, G., Francois, R., Heinze, C., Maier-Rimer, E., Marin Jezequel, V., Nelson, D. M., and Queguiner, B., 2000, A review of the silicon cycle in the modern ocean:recent progress and missing gaps in the application of iogenic opal as a paleo productivity proxy: Global and Planetary Change, v. 26, p. 317-365.

Rinehart, J. S., 1980, Geysers and Geothermal Energy: New York, Springer-Verlag, 237 p.

Roberts, J. A., Bennett, P. C., Gonzalez, L. A., Macpherson, G. L., and Milliken, K. L., 2004, Microbial precipitation of dolomite in methanogenic groundwater: Geology v. 32, p. 277-280.

Rogers, J. R., Bennett, P. C., and Choi, W. J., 1998, Feldspars as a source of nutrients for microorganisms: American Mineralogist, v. 83, p. 1532-1540. 
Rosen, M. R., Miser, D. E., Starcher, M. A., and Warren, J. K., 1989, Formation of dolomite in the Coorong Region, South Australia: Geochimica et Cosmochimica Acta, v. 53, p. 661-669.

Sarbu, S. M., and Popa, R., 1992, A unique, autotrophically based cave ecosystem, in Camacho, A. I., editor, The Natural History of Biospeleology: Madrid, Museo Nacional de Ciencias Naturales, Cosejo Superior de Investigaciones Cientificas, p. 637-666.

Sarbu, S. M., Kinkle, B. K., Vlasceanu, L., Kane, T. C., and Popa, R., 1994, Microbiological characterization of a sulfide-rich groundwater ecosystem: Geomicrobiology Journal, v. 12, p. 175-182.

Schieber, J., 1999, Microbial mats in terrigenous clastics: the challenges of identification in the rock record: Palaois, v. 14, p. 3-12.

Schultze-Lam, S., Thompson, J. B., and Beveridge, T. J., 1993, Metal ion immobilisation by bacterial surfaces in freshwater environments: Water Pollution Research Journal of Canada, v. 28, p. 51-81.

Schultze-Lam, S., Ferris, F. G., Konhauser, K. O., and Wiese, R. G., 1995, In situ silicification of an Icelandic hot spring microbial mat: implications for microfossil formation: Canadian Journal of Earth Sciences, v. 32, p. 2021-2026.

Southam, G., and Beveridge, T. J., 1992, Enumeration of thiobacilli within pH neutral and acidic mine tailings and their role in the development of secondary mineral soil: Applied and Environmental Microbiology, v. 58, p. 1904-1912.

Stevens, T. O., McKinley, J. P., and Fredrickson, J. K., 1993, Bacteria associated with deep, alkaline groundwaters in southeast Washington: Microbial Ecology, v. 25, p. 35-50.

Stumm, W., and Morgan, J. J., 1996, Aquatic Chemistry: New York, Wiley, 1022 p.

Tazaki, K., 1997, Biomineralization of layer silicates and hydrated Fe/Mn oxides in microbial mats: an electron microscopical study: Clays and Clay Mineralogy, v. 42, p. 402-408.

Thompson, J. B., Ferris, F. G., and Smith, D. A., 1990, Geomicrobiology and sedimentology of the mixolimnion and chemocline in Fayettville Green Lake, New York: Palaios, v. 5, p. 52-75.

Turner, R. E., and Rabalais, N. N., 1994, Coastal eutrophication near the Mississippi Delta: Nature, v. 368, p. $619-621$

Urrutia, M. M., and Beveridge, T. J., 1994. Formation of fine-grained metal and silicate precipitates on a bacterial surface (Bacillus subtilis): Chemical Geology, v. 116, p. 261-280.

Urrutia, M. M., Kemper, M., Doyle, R., and Beveridge, T. J., 1992, The membrane-induced proton motive force influences the metal binding ability of Bacillus subtilis cell walls: Applied and Environmental Microbiology, v. 58, p. 3837-3844.

van Lith, Y., Vasconcelos, C., Warthmann, R., Martins, J. C. F., and Mckenzie, J. A., 2002, Bacterial sulfate reduction and salinity: two controls on dolomite precipitation in Lagoa Vermelha and Brejo do Espinho (Brazil): Hydrobiologia, v. 485, p. 35-49

van Loosdrecht, M. C. M., Lyklema, J., Norde, W., and Zehnder, A. J. B., 1990, Influences of surfaces on microbial activity: Microbiological Reviews, v. 54, p. 75-87.

Vasconcelos, C., and McKenzie, J. A., 1997, Microbial mediation of modern dolomite precipitation and diagenesis under anoxic conditions (Lagoa Vermelha, Rio de Janeiro, Brazil): Journal of Sedimentary Research, v. 67, p. 378-390.

Vasconcelos, C., Mckenzie, J. A., Bernasconi, S., Grujic, D., and Yien, A. J., 1995, Microbial mediation as a possible mechanism for natural dolomite formation at low temperatures: Nature, v. 377, p. 220-224.

Von der Borsch, C. C., 1965, The distribution and preliminary geochemistry of modern carbonate sediments of the Coorong area, South Australia: Geochimica et Cosmochimica Acta, v. 29, p. 781-799.

Walker, S. G., Flemming, C. A., Ferris, F. G., Beveridge, T. J., and Bailey, G. W., 1989, Physicochemica interaction of Escherichia coli cell envelopes and Bacillus subtilis cell walls with two clays and the ability of the composite to immobilize heavy metal from solution: Applied and Environmental Microbiology, v. 55, p. $2976-2984$

Warren, L. A., and Ferris, F. G., 1998, Continuum between sorption and precipitation of Fe(III) on microbial surfaces: Environmental Science and Technology, v. 32, p. 2331-2337.

Warren, L. A., and Haack, E. A., 2001, Biogeochemical controls on metal behaviour in freshwater environments: Earth Science Reviews, v. 54, p. 261-320.

Whipkey, C. E., Capo, R. C., Hsieh, J. C. C., and Chadwick, O. A., 2002, Development of magnesian carbonates in Quaternary soils on the Island of Hawaii: Journal of Sedimentary Research, v. 72 p. $158-165$.

Wierzchos, J., and Ascaso, C., 2001, Life, decay, and fossilisation of endolithic microorganisms from the Ross Desert, Antarctica: suggestions for in situ further research: Polar Biology, v. 24, p. 863-868.

— 2002, Microbial fossil record from the Ross Desert, Antarctica: implication in the search for past life on Mars: International Journal of Astrobiology, v. 1, p. 51-59.

Wierzchos, J., Ascaso, C., Sancho, L. G., and Green, A., 2003, Iron-rich diagenetic minerals are biomarkers of microbial activity in Antarctic rocks: Geomicrobiology Journal, v. 20, p. 15-24.

Wierzchos, J., Sancho, L. G., and Ascaso, C., 2004, Biomineralization of endolithic microbes in rocks from the McMurdo Dry Valleys of Antarctica: implications for microbial fossil formation and their detection: Environmental Microbiology, v. 8, p. 1-10.

Wright, D. T., 1997, An organogenic origin for widespread dolomite in the Cambrian Eilean Dubh Formation, Northwestern Scotland: Journal of Sedimentary Research, v. 67, p. 54-64.

1999, The role of sulfate reducing bacteria and cyanobacteria in dolomite formation in distal lakes of the Coorong region, South Australia: Sedimentary Geology, v. 126, p. 147-157.

Yee, N., Phoenix, V. R., Konhauser, K. O., Benning, L. G., and Ferris, F. G., 2003, The effect of cyanobacteria on $\mathrm{Si}$ precipitation kinetics at neutral $\mathrm{pH}$ : implications for bacterial silicification in geothermal hot springs: Chemical Geology, v. 99, p. 83-90. 